University of Nebraska - Lincoln

DigitalCommons@University of Nebraska - Lincoln

Publications, Agencies and Staff of the U.S.

Department of Commerce

U.S. Department of Commerce

1983

\title{
Abundance and Biomass of the Meiobenthos in Nearshore Lake Michigan with Comparisons to the Macrobenthos
}

Thomas F. Nalepa

National Oceanic and Atmospheric Administration, thomas.nalepa@noaa.gov

Michael A. Quigley

National Oceanic and Atmospheric Administration

Follow this and additional works at: https://digitalcommons.unl.edu/usdeptcommercepub

Part of the Environmental Sciences Commons

Nalepa, Thomas F. and Quigley, Michael A., "Abundance and Biomass of the Meiobenthos in Nearshore Lake Michigan with Comparisons to the Macrobenthos" (1983). Publications, Agencies and Staff of the U.S. Department of Commerce. 386.

https://digitalcommons.unl.edu/usdeptcommercepub/386

This Article is brought to you for free and open access by the U.S. Department of Commerce at DigitalCommons@University of Nebraska - Lincoln. It has been accepted for inclusion in Publications, Agencies and Staff of the U.S. Department of Commerce by an authorized administrator of DigitalCommons@University of Nebraska - Lincoln. 


\title{
ABUNDANCE AND BIOMASS OF THE MEIOBENTHOS IN NEARSHORE LAKE MICHIGAN WITH COMPARISONS TO THE MACROBENTHOS
}

\author{
Thomas F. Nalepa and Michael A. Quigley \\ National Oceanic and Atmospheric Administration \\ Great Lakes Environmental Research laboratory \\ 2300 Washtenaw Avenue \\ Ann Arbor, Michigan 48104
}

\begin{abstract}
The meiobenthos of nearshore southeastern Lake Michigan was quantified by taking cores from three depths $(11,17$, and $23 \mathrm{~m}$ ) at monthly intervals from May to November 1976-79. Total meiobenthic abundance ranged from $69,700 / \mathrm{m}^{2}$ to $1,300,000 / \mathrm{m}^{2}$ and total biomass ranged from 0.03 to $0.87 \mathrm{~g} / \mathrm{m}^{2}$. Nematodes accounted for $80 \%$ of all individuals and $66 \%$ of the biomass. Most of the major groups peaked in late spring/summer, but some peaked in early spring and fall. With the exception of nematodes, mean annual densities varied from two-fold to twelve-fold at a given station. Harpacticoids, tardigrades, and ostracods tended to be more abundant at the deeper depths, while cyclopoids and cladocerans were less abundant. There was no consistent relationship between sampling depth and the abundance of nematodes and rotifers. Temporal and spatial variation in many of the groups appeared related to changes in the amount of bottom detritus. The overall macrobenthos:meiobenthos biomass ratio was 15:1 and ranged from 5:1 to 45:1 on an annual basis. ADDITIONAL INDEX WORDS: Metabolism, nematodes, aquatic animals, detritus.
\end{abstract}

\section{INTRODUCTION}

While there have been many surveys of the macrobenthos in the Great Lakes during the past few decades, particularly in nearshore Lake Michigan (Mozley and Garcia 1972, Mozley 1975, Stimpson et al. 1975), there have been no truly quantitative surveys of the Great Lakes meiobenthos. Although several recent studies have given the abundance of some meiobenthic groups (Cook 1975, Loveridge and Cook 1976, Evans and Stewart 1977, Golini 1979), the mesh size used in these studies $(\geqslant 100 \mu \mathrm{m})$ was too large to retain all meiobenthic individuals (Nalepa and Robertson 1981a). In addition, the biomass of the meiobenthos has never been estimated.

Because of their great densities and relatively high metabolic rates, these small forms play an integral role in cycling materials through the benthic system (McIntyre 1969, Gerlach 1971 and 1978). Also, activities of the meiobenthos have been shown to change the character of the sediments (Cullen 1973, Riemann and Schrage 1978), to enhance the mineralization of organic material by bacteria (Lee et al. 1975), and to increase the net incorporation of detrital food by the macrobenthos (Tenore et al. 1977).

We here present the results of a 4-year survey of the meiobenthos in a nearshore region of southeastern Lake Michigan. We describe depth distributions and seasonal and year-to-year variations of the major groups, and assess the meiobenthos in relation to the macrobenthos.

\section{DESCRIPTION OF STUDY AREA}

The study area in southeastern Lake Michigan extended $4 \mathrm{~km}$ from shore and $5 \mathrm{~km}$ north of the Grand River (Fig. 1). Bathymetry in this part of the lake is that of a sloping shelf. Sediments are primarily sandy lag deposits-finer sediment materials are swept off the shelf into deeper waters by wave action and offshore currents.

The Grand River strongly affects the lake environment in the immediate area around its mouth. Sixty-nine communities discharge wastes into the river's basin (Great Lakes Basin Commission 1975), and concentrations of trace metals and nutrients at the mouth are up to 49 times higher than background lake levels (Eadie et al. 1978). Also, lake 


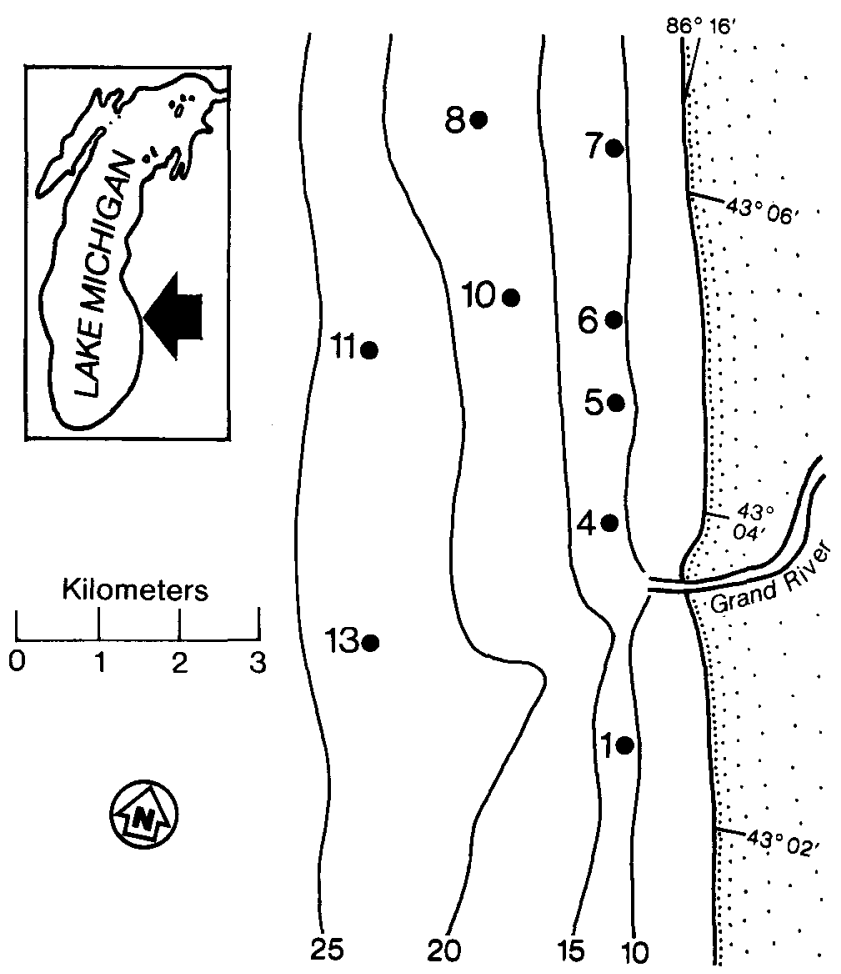

FIG. 1. Location of sampling stations in southeastern Lake Michigan. Depth contours in meters.

sediments around the mouth have higher concentrations of total organic carbon and phosphorus when compared to similar areas farther north or south (Chambers and Eadie 1980). Loading of suspended solids into the lake by the river amounts to about $1.2 \times 10^{8} \mathrm{~kg} / \mathrm{yr}$; this represents $16 \%$ of the total loading into Lake Michigan (Sonzogni et al. 1978). Much of the loading occurs in spring during the period of high flow. Mean discharge of the river is $96 \mathrm{~m}^{3} / \mathrm{s}$, but the river plume is small in extent, rarely exceeding $10 \mathrm{~km}^{2}$.

\section{METHODS}

The meiobenthos was sampled from five stations at $11 \mathrm{~m}$, two stations at $17 \mathrm{~m}$, and two stations at $23 \mathrm{~m}$ depth (Fig. 1). All nine stations were sampled in 1976, but only four were sampled in 1977 (Stations $4,7,10,11$ ) and two in 1978 and 1979 (Stations 4,7 ). Samples were generally taken on a monthly basis from May to November each year; however, not all stations were sampled on some dates because of adverse weather conditions.

All benthic samples were taken by divers using SCUBA. Four cores were generally taken at each station on each sampling date. A clear, acrylic tube, 23 or $30 \mathrm{~cm}$ long and $5 \mathrm{~cm}$ in diameter, was forced into the sediment (penetration 7 to $12 \mathrm{~cm}$ ), stoppered at both ends, and placed upright in a plastic carrying basket. After the samples were brought to the surface, the amount of surface detritus was measured to the nearest $\mathrm{mm}$. For samples collected in 1976-77, the water above the sediments in the core tube was decanted and preserved in $5 \%$ formalin. This water was later analyzed to distinguish between epibenthic and benthic forms. The sediments were frozen, then thawed and preserved in 10\% formalin containing rose bengal stain. For samples collected in 1978-79, the water overlying the sediments in the core tube was not decanted and some samples were never frozen, but preserved in formalin immediately.

The sediments were washed through a succession of screens with mesh openings of $595 \mu \mathrm{m}, 106 \mu \mathrm{m}$, and $45 \mu \mathrm{m}$. An additional screen with openings of $250 \mu \mathrm{m}$ was used for the 1978-79 samples. Since most of the substrate was retained on either the $250-\mu \mathrm{m}$ or $106-\mu \mathrm{m}$ screen, the organisms retained by these screens were separated from the substrate by vigorous mixing in a sugar solution, followed by decantation. All organisms retained on each screen were transferred to a gridded petri dish and counted and sorted under $25 \mathrm{X}$ magnification. The organisms were later identified to the lowest practical taxonomic level. The water collected above the sediments in each of the 1976-77 cores was washed through a $64-\mu \mathrm{m}$ mesh plankton bucket and all individuals except pelagic rotifers were counted and identified.

Standing stocks (dry weight biomass) of all taxa except oligochaetes were estimated by multiplying abundance by a determined dry weight (Nalepa and Quigley 1980 and 1981, Nalepa and Robertson 1981a). Oligochaete standing stocks in a given sample were estimated by measuring the total length of all individuals retained by each screen and then multiplying by a length/weight conversion factor. A conversion factor for each screen was derived from individuals freshly killed by freezing. Since oligochaetes preserved immediately in formalin tended to be more contracted than those initially frozen, it was necessary to apply a correction factor to the total length of oligochaetes in the cores preserved in formalin before converting to dry weight biomass (Nalepa and Quigley 1981).

Following the recommendation of McIntyre (1969), the meiobenthos is here defined on the basis of taxonomic distinctions and includes the follow- 
ing forms: nematodes, copepods, cladocerans, ostracods, tardigrades, turbellarians, rotifers, water mites, and coelenterates (hydra). By definition, the term "meiobenthos" includes all forms in the sediments at the time of sampling. However, because the cores contained both sediments and the water immediately overlying the sediments, it was necessary to distinguish between the individuals occurring in these two portions of the sample. In 1977, water samples were taken just above the bottom by divers at the same time the sediment cores were taken. A comparison of the number and kinds of organisms in these water samples to the number and kinds of organisms found in the water overlying the sediments in the core samples (which was decanted off) indicated that most taxa were more abundant (per unit volume) in the water in the sediment core samples (unpublished data). This indicates movement out of the sediments into the water overlying the sediments after the cores were collected and during diver ascent. Our estimates of abundance are therefore based on the total number of organisms collected in the core samples (both water and sediments) with the exception of the following taxa: Tropocyclops prasinus mexicanus, all calanoid copepodids and adults except Eurytemora affinis, Alonella sp., Bosmina longirostris, Eubosmina coregoni, and Latona setifera. These taxa were more abundant in the water samples than in the sediment core water samples, and are not here considered a part of the meiobenthos. The macrobenthos included the following groups: oligochaetes, amphipods, chironomids, sphaeriids, gastropods, and leeches.

Bottom temperatures were recorded at Stations $4,7,10$, and 11 each time samples were taken.

All statistical tests were conducted using nonparametric procedures. We could not achieve homogeneity of variances for some of the groups, even after transformation.

\section{RESULTS}

\section{Benthic Environment}

The following descriptions of the bottom sediments are based on measurements taken from intact sediment cores and on direct observations by divers. Fine to very fine sand predominated at $11 \mathrm{~m}$ and $17 \mathrm{~m}$ and coarse to medium sand occurred at $23 \mathrm{~m}$. Wave-induced ripple marks were most evident at $11 \mathrm{~m}$ and decreased in size with increased depth until the sediment surface at $23 \mathrm{~m}$ was almost flat. The bottom was characterized by the presence of a detrital layer that occurred over the sandy substrate (Fig. 2). At the 11-m depth, detrital amounts were generally greatest in spring and declined throughout summer, until little or no detritus was observed in fall. The spring increase was likely a result of loading from the Grand River during spring runoff and/or the "rain" of autochthonous material from the spring phytoplankton
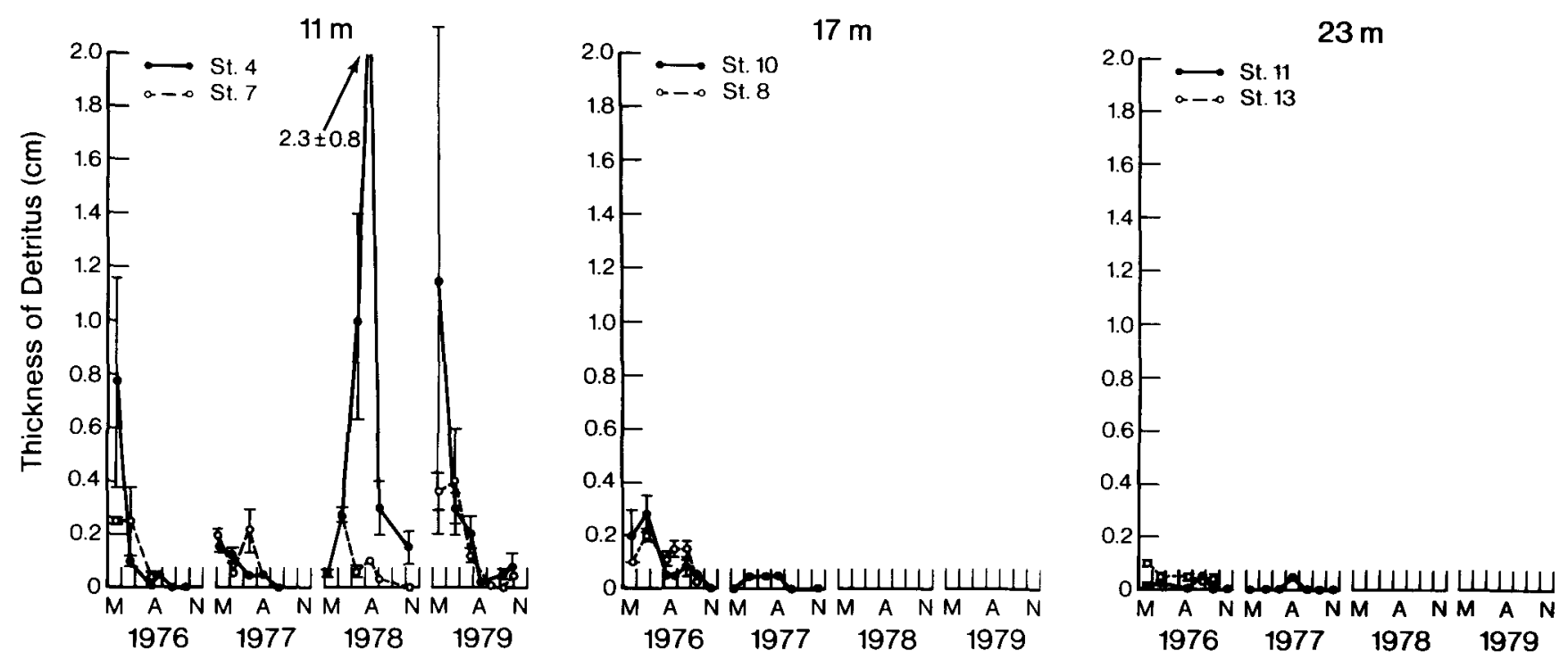

FIG. 2. Seasonal and annual fluctuations in the amount of bottom detritus at the various stations. A mounts of detritus at the three 11-m stations sampled only in 1976 (Stations 1,5,6) are not shown, but amounts at these stations were within the ranges found at Stations 4 and 7. 
bloom. The subsequent decline was likely a result of the detritus being resuspended by wave action and transported to deeper regions of the lake. After storm events, suspended detritus was very apparent in the near-bottom waters. This seasonal pattern was evident in 1976, 1977, and 1979. In 1978, however, there was a thick, local patch of detritus at the station nearest the river mouth (Station 4) throughout summer (Fig. 2). In general, the total amount of detritus and the extent of seasonal fluctuations decreased with increased sampling depth.

Year-to-year variations in the amount of detritus appeared to be related to annual differences in the peak discharge of the river. Maximum discharge in spring 1976 was $796 \mathrm{~m}^{3} / \mathrm{s}$; this was the highest flow recorded in 44 years. In turn, detrital accumulations in spring 1976 were the most extensive and widespread of the 4-year sampling period. Detritus covered the entire bottom at all the $11-\mathrm{m}$ and $17-\mathrm{m}$ stations, with patches of greater thickness clearly evident at the station nearest the river mouth. In 1977 the peak flow of the river was very low, only $241 \mathrm{~m}^{3} / \mathrm{s}$. Consequently, minimum amounts of detritus were observed, particularly at the deeper depths (Fig. 2). In addition, there were no patches of greater accumulations evident at any of the stations. Peak flow rates in 1978 and 1979 were about average, $476 \mathrm{~m}^{3} / \mathrm{s}$ and $493 \mathrm{~m}^{3} / \mathrm{s}$, respectively. In these 2 years, the distribution of detritus was more patchy than in previous years. As noted earlier, one such patch in 1978 persisted at Station 4 until fall.

Mean bottom temperatures at the $11-\mathrm{m}, 17-\mathrm{m}$, and 23-m depths for all sampling dates in 1976 and 1977 were $12.0^{\circ}, 11.3^{\circ}$, and $9.1^{\circ} \mathrm{C}$, respectively. Broad temperature fluctuations were apparent at all three depths during the period of summer stratification (June-September). This may be attributed to the rocking of the thermocline by seiches, downwellings, and upwellings (Siebel and Ayers 1977, Mozley and Winnell 1975). Temperature fluctuations were particularly apparent at the shallower depths. To indicate the extent of these fluctuations, the mean monthly and daily range of temperatures at the Muskegon water plant intake, located about $10 \mathrm{~km}$ north of the study site at a depth of $11 \mathrm{~m}$, are given in Table 1.

\section{Density, Biomass, and Composition}

The overall mean density of the meiobenthos over a 4-year period was $302,500 / \mathrm{m}^{2}$ and ranged from
TABLE 1. Monthly mean and daily range of water temperatures $\left(C^{\circ}\right)$ at the Muskegon Water Treatment Plant in 1976, 1977, 1978, and 1979. The intake was located in $11 \mathrm{~m}$ of water about $10 \mathrm{~km}$ north of our study site.

\begin{tabular}{lcccr}
\hline \hline & 1976 & 1977 & \multicolumn{1}{c}{1978} & \multicolumn{1}{c}{1979} \\
\hline Apr & $7(6-10)$ & $5(2-7)$ & $4(2-6)$ & $3(1-4)$ \\
May & $8(6-10)$ & $9(6-14)$ & $6(4-9)$ & $7(4-11)$ \\
Jun & $13(6-19)$ & $9(6-14)$ & $10(6-16)$ & $11(7-16)$ \\
Jul & $12(6-20)$ & $16(6-23)$ & $12(6-18)$ & $9(6-19)$ \\
Aug & $16(7-23)$ & $16(7-21)$ & $18(8-22)$ & $14(6-20)$ \\
Sep & $16(9-20)$ & $14(7-21)$ & $19(13-23)$ & $13(5-21)$ \\
Oct & $14(11-19)$ & $10(7-15)$ & $14(8-16)$ & $12(6-14)$ \\
Nov & $8(6-11)$ & $9(6-11)$ & $10(7-12)$ & $10(8-12)$ \\
\hline
\end{tabular}

69,700 to $1,300,000 / \mathrm{m}^{3}$ at a given station on a given date; mean dry-wt biomass was $0.32 \mathrm{~g} / \mathrm{m}^{2}$ and ranged from 0.03 to $0.87 \mathrm{~g} / \mathrm{m}^{2}$. As an indication of the reliability of our density and biomass estimates, standard error values as a percentage of the mean were caluclated for each station on each sampling date. The standard errors averaged $18 \%$ and $16 \%$ of the mean for total density and biomass, respectively.

Nematodes were by far the most abundant and widespread meiobenthic group, accounting for $80 \%$ of all meiobenthic individuals and $66 \%$ of the biomass. Nematodes were found in every single core collected during the 4-year period. Other meiobenthic groups, although not as consistently abundant as nematodes, became prominent at a given station, depending on the sampling date and depth. These groups were cyclopoid copepods, cladocerans, harpacticoid copepods, tardigrades, and rotifers. Two other groups, ostracods and turbellarians, were common, but densities were always relatively low. Water mites and coelenterates were found only occasionally.

Abundances of individual species have been given by Nalepa and Quigley $(1980,1981)$ and will not be detailed here. Of the groups considered to be part of the meiobenthos, only copepods and cladocerans were determined to the species level. Eight cyclopoid species were identified, with Cyclops bicuspidatus thomasi and Cyclops vernalis accounting for $91 \%$ of all cyclopoid adults. All cyclopoid copepodid stages were collected in the sediments, with stage IV accounting for $61 \%$ of the total copepodid number. Overall, adults accounted for $41 \%$ of the total number of cyclopoids. Harpacticoid copepods were numerically dominated by Canthocamptus robertcokeri, Canthocamptus staphylinoides, Bryocamptus cf. vejdov- 
skyi, and Bryocamptus nivalis. Four other harpacticoid species were rare. Eurytemora affinis was the only calanoid copepod considered part of the meiobenthos. The most abundant of the 10 cladoceran species were Alona affinis, Eurycercus lamellatus, Ilyocryptus acutifrons, Ilyocryptus sordidus, and Leydigia quadrangularis. Rotifers were not identified to species, but most appeared to be of the family Dicranophoridae.

The mean abundance and biomass of the macrobenthos were $22,300 / \mathrm{m}^{2}$ and $4.65 \mathrm{~g} / \mathrm{m}^{2}$. These estimates may be higher than those of other macrobenthic surveys in southeastern Lake Michigan since our estimates include many oligochaetes (particularly naidids) and chironomids usually not retained by the larger mesh screens used in other surveys (Nalepa and Robertson 1981a). Most of the macrobenthos were identified to the species level. Composition of the macrobenthos is given below as the total number of taxa in each major group, the dominant taxa in the group, and the percentage each dominant taxa represented of the total number of individuals in the group: Tubificidae-16 species, immature without hair setae (89\%); Naididae-17 species, Vejdovskyella intermedia (51\%) and Amphichaeta sp. (34\%); Amphipoda-2 species, Pontoporeia hoyi (99.6\%); Gastropoda-5 species, Valvata sincera (75\%); Chironomidae-27 species, Cladotanytarsus sp. (13\%), Polypedilum scalaeum (10\%), Paracladopelma undine (10\%), and Saetheria tylus (10\%). Sphaeriids were identified only to genus, and Pisidium sp. accounted for $72 \%$ of all individuals.

\section{Seasonal and Year-to-Year Variation}

Seasonal and annual fluctuations in abundance of the major meio- and macrobenthic groups are shown in Figures 3 and 4. The meiobenthic groups displaying the most consistent seasonal trends were cyclopoids and cladocerans. Densities of these two groups were low in spring, increased to a peak in late spring/summer, and then declined in fall in each of the 4 years. Cyclopoids usually peaked in June, while cladocerans peaked in August. The high density of cyclopoids in August 1979 at Station 4 (Fig. 3) was due to a large number (532) of stage IV copepodids in just one of the replicate cores.

Seasonal trends in the abundance of nematodes, harpacticoids, and rotifers were more variable. In 1976, 1978, and 1979, densities of these three groups were low in the spring and then increased in late spring/summer. In 1977, however, densities were high on the first sampling date (2 May) and then declined throughout summer. The early spring peak of rotifers in 1977 occurred at all stations, but the peak of nematodes occurred only at the $17-\mathrm{m}$ and $23-\mathrm{m}$ stations and the peak of harpacticoids occurred only at the $23-\mathrm{m}$ station (Fig. 3 ). At times, a secondary increase in these three groups occurred in the fall, but fall peaks were again not evident at all stations, or even consistent among years at the same station. The fall peak of harpacticoids occurred only at the $17-\mathrm{m}$ and $23-\mathrm{m}$ stations and was due solely to an increase in the number of Bryocamptus nivalis.

Significant annual differences at a given station were determined by first dividing the sampling dates into three periods (spring, summer, fall) and then comparing mean densities between years for each period. As indicated in Figures 3 and 4, significant $(P<0.05)$ annual differences were apparent at each station for most of the groups in at least one of the three sampling periods. Only nematode and cyclopoid densities at Station 4 and cyclopoid densities at Station 7 did not vary significantly from one year to the next. The abundance of nematodes at Station 4 was remarkably consistent on a yearly basis, but the abundance of cyclopoids was so variable within a given seasonal period that significant year-to-year differences could not be detected.

The mean annual density of all meiobenthic groups except nematodes varied from two- to almost twelve-fold at a given station. The most notable variation was the eight-fold decrease in the number of tardigrades between 1976 and 1977 at the $17-\mathrm{m}$ and 23-m stations (Stations 10 and 11) (Fig. 3). Densities of many groups were unusually high in 1978. Maximum peaks at the 11-m depth were recorded in the summer of that year for the following groups: cyclopoids $\left(91,900 / \mathrm{m}^{2}\right)$, cladocerans $\left(75,500 / \mathrm{m}^{2}\right)$, rotifers $\left(77,300 / \mathrm{m}^{2}\right)$, and harpacticoids $\left(33,200 / \mathrm{m}^{2}\right)$.

We used Kendall's rank correlation analysis (Sokal and Rohlf 1969) to determine if abundances in a given year were related to amounts of surface detritus (Table 2). There were many significant $(P<0.05)$ correlations for both the meio- and macrobenthos, suggesting that yearly differences in amounts of detritus may account for some of the year-to-year variation in abundance found in many of the groups. Most correlations were positive, but negative correlations were evident for Stylodrilus heringianus, sphaeriids, and chironomids. 
Seasonal and annual fluctuations in total meiobenthic biomass at the 11-, 17-, and 23-m depths are given in Figure 5. Most temporal variations at $11 \mathrm{~m}$ reflected changes in the abundance of nematodes, cyclopoids, and cladocerans, while variation at the $17-\mathrm{m}$ and $23-\mathrm{m}$ depths reflected changes in the abundance of nematodes and harpacticoids.

\section{Station Differences}

Besides indicating temporal variation at the same station, Figures 3 and 4 also show the extent of variation between stations of the same depth. Of particular interest are comparisons between two of the $11-\mathrm{m}$ stations, Stations 4 and 7 . The former station was located nearest the river mouth and the latter was located farthest away. Although there were differences between the two stations within any given year, most differences were not consistent from one year to the next. For instance, peak densities of cladocerans and tubificids were greater at Station 7 in 1977, but greater at Station 4 in 1978. Of the major groups, only naidids were consistently more abundant at one of the stations, with greater peak densities at Station 4 in each of the 4 years. Overall differences between Stations 4 and 7 were greatest in 1978. In that year, mean densities of cladocerans, cyclopoids, naidids, and tubificids were 2 to 15 times greater at Station 4, while harpacticoids were two times more abundant at Station 7. As noted earlier, far greater amounts of detritus were present at Station $\mathbf{4}$ than at Station 7 in 1978. Abundances at the three $11-\mathrm{m}$ stations sampled only in 1976 (Stations 1, 5, 6) were generally within the range found at Stations 4 and 7.

The most noteworthy difference between the two $17-\mathrm{m}$ stations, Stations 8 and 10 , was the greater number of nematodes at the former station. The mean annual density of nematodes at Station 8 in 1976 was $576,000 / \mathrm{m}^{2}$, compared to only $245,700 / \mathrm{m}^{2}$, at Station 10. Tubificids, Stylodrilus heringianus, and sphaeriids also tended to be more abundant at Station 8 (Fig. 4). Although abundances at the two 23-m stations, Stations 11 and 13, may have been different on a given sampling date, mean annual abundances at these two stations were similar for all the groups.

Since more stations were sampled in 1976 than in any other year, we used correlation analysis to determine if spatial distributions in that year were related to the spatial distribution of detritus. As indicated in Table 3, many groups were again positively associated with this material. The only negative correlation was for nematodes at the $11-\mathrm{m}$ depth in the spring.

\section{Depth Differences}

The mean annual abundance and biomass of the various meiobenthic groups at the $11-\mathrm{m}, 17-\mathrm{m}$, and 23-m depths in both 1976 and 1977 are given in Table 4. Differences in density each year were tested using the Kruskal-Wallis test and the multisample extension of the median test (Conover 1971). A significant difference $(P<0.05)$ between depths in at least 1 year occurred in all groups except turbellarians. Tardigrades, harpacticoids, and ostracods tended to be most abundant at either 17 or $23 \mathrm{~m}$. Of these three groups, the distribution of tardigrades was the most clearly defined; this group was consistently more abundant at $17 \mathrm{~m}$ than at either 11 or $23 \mathrm{~m}$. This was particularly true in 1976 when the mean annual density of tardigrades at $17 \mathrm{~m}$ was four times the mean density at $23 \mathrm{~m}$, and 35 times the mean density at $11 \mathrm{~m}$. Although most harpacticoid species were equally or more abundant at 17 or $23 \mathrm{~m}$ than at $11 \mathrm{~m}$, the most dramatic depth difference occurred in the distribution of Bryocamptus nivalis. The mean annual density of this species at 11 and $17 \mathrm{~m}$ was less than $200 / \mathrm{m}^{2}$ in both 1976 and 1977 , but the mean density at $23 \mathrm{~m}$ was $3,600 / \mathrm{m}^{2}$ in 1976 and $10,200 / \mathrm{m}^{2}$ in 1977 . Ostracods also tended to be most abundant at $23 \mathrm{~m}$.

Consistent trends between sampling depth and the abundance of either nematodes or rotifers were not apparent. Nematodes were more abundant at $17 \mathrm{~m}$ in 1976, but this can be attributed to unusually high densities at just one of the $17-\mathrm{m}$ stations, Station 8 (not sampled in 1977). Rotifers tended to be more abundant at 17 and $23 \mathrm{~m}$ in 1976 but not in 1977.

Cyclopoids and cladocerans were the only meiobenthic groups that decreased in abundance with increasing depth. This trend was evident for all taxa and life stages in these two groups, with the exception of nauplii, which were equally abundant at all three depths.

Overall, the mean biomass of the meiobenthos at 11,17 , and $23 \mathrm{~m}$ in 1976 and 1977 was $0.28,0.39$, and $0.28 \mathrm{~g} / \mathrm{m}^{2}$, respectively. Nematodes accounted for a greater percentage of the total meiobenthic biomass as depth increased, accounting for $65 \%$, $78 \%$, and $82 \%$ of the biomass at the three depths. This may be attributed to the decline in the biomass of cyclopoids and cladocerans at the deeper depths. These two groups accounted for $28 \%$ of meio- 

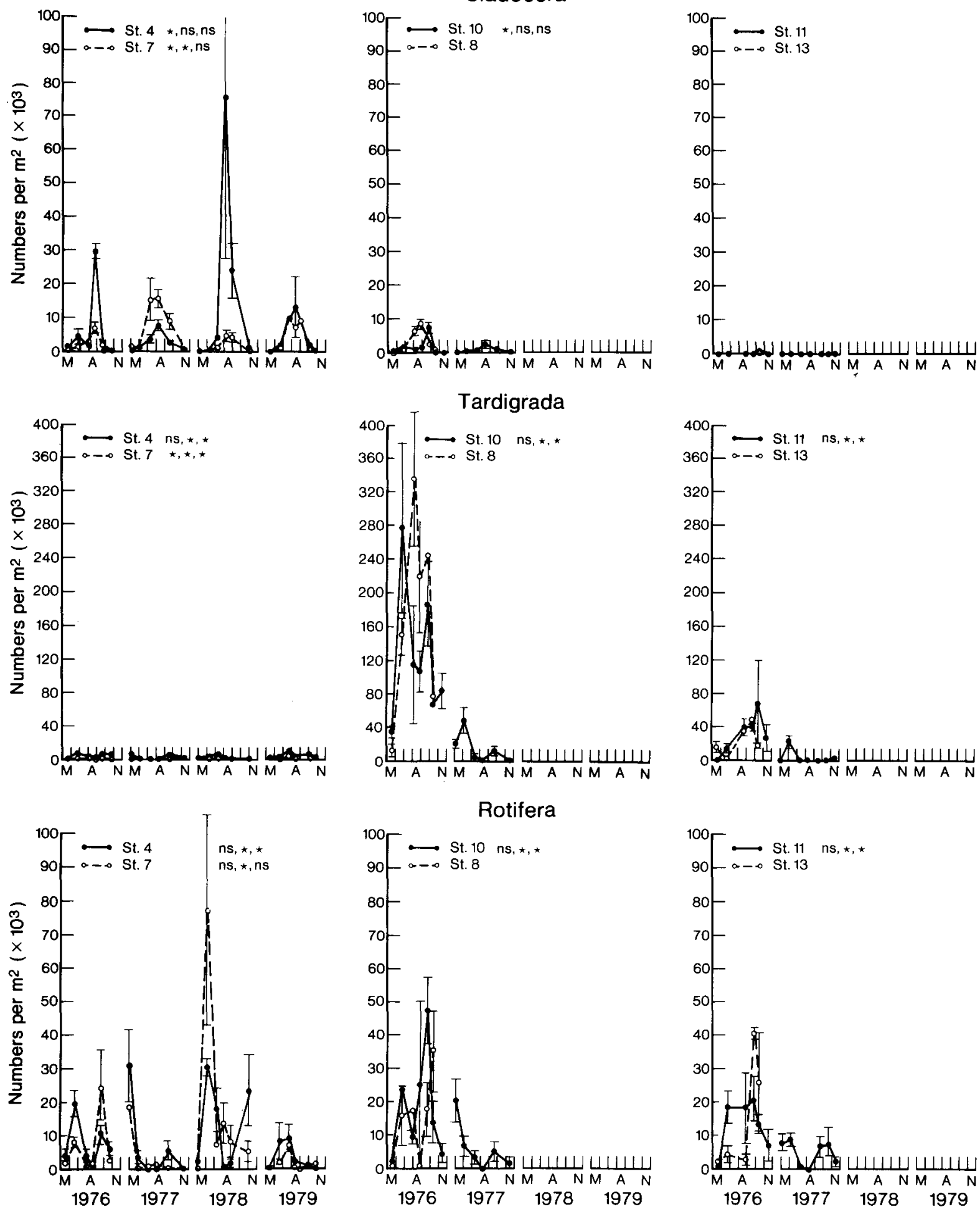

Rotifera
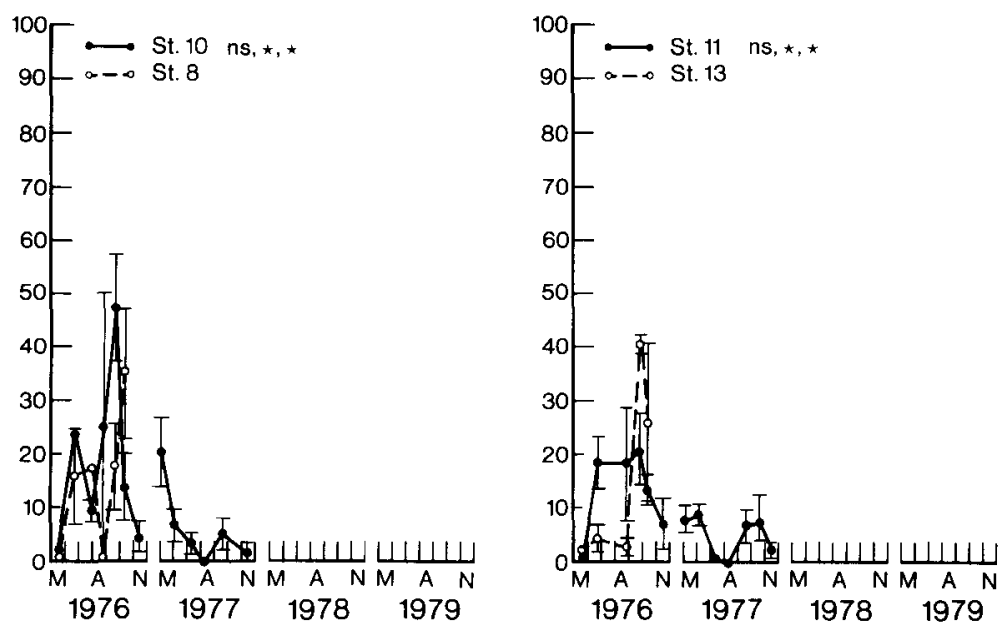

FIG. 3. Mean (SE) density of the major meiobenthic groups on each sampling date, 1976-79. Note the different scales for Nematoda and Tardigrada. Significant differences between years for the spring, summer, and fall periods were determined by using the Kruskal-Wallis test at Stations 4 and 7 and by using the Mann-Whitney test at Stations 10 and 

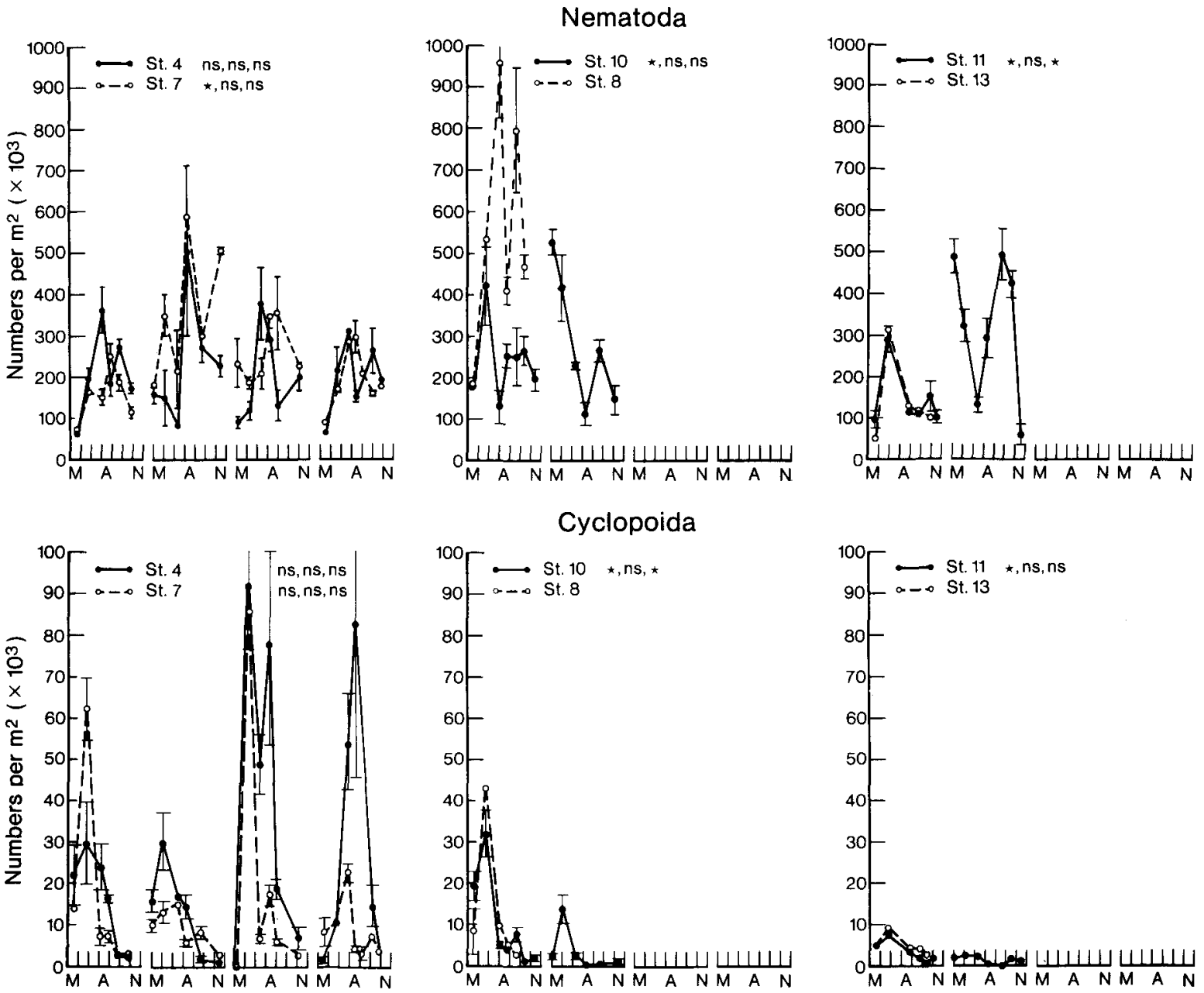

\section{Cyclopoida}
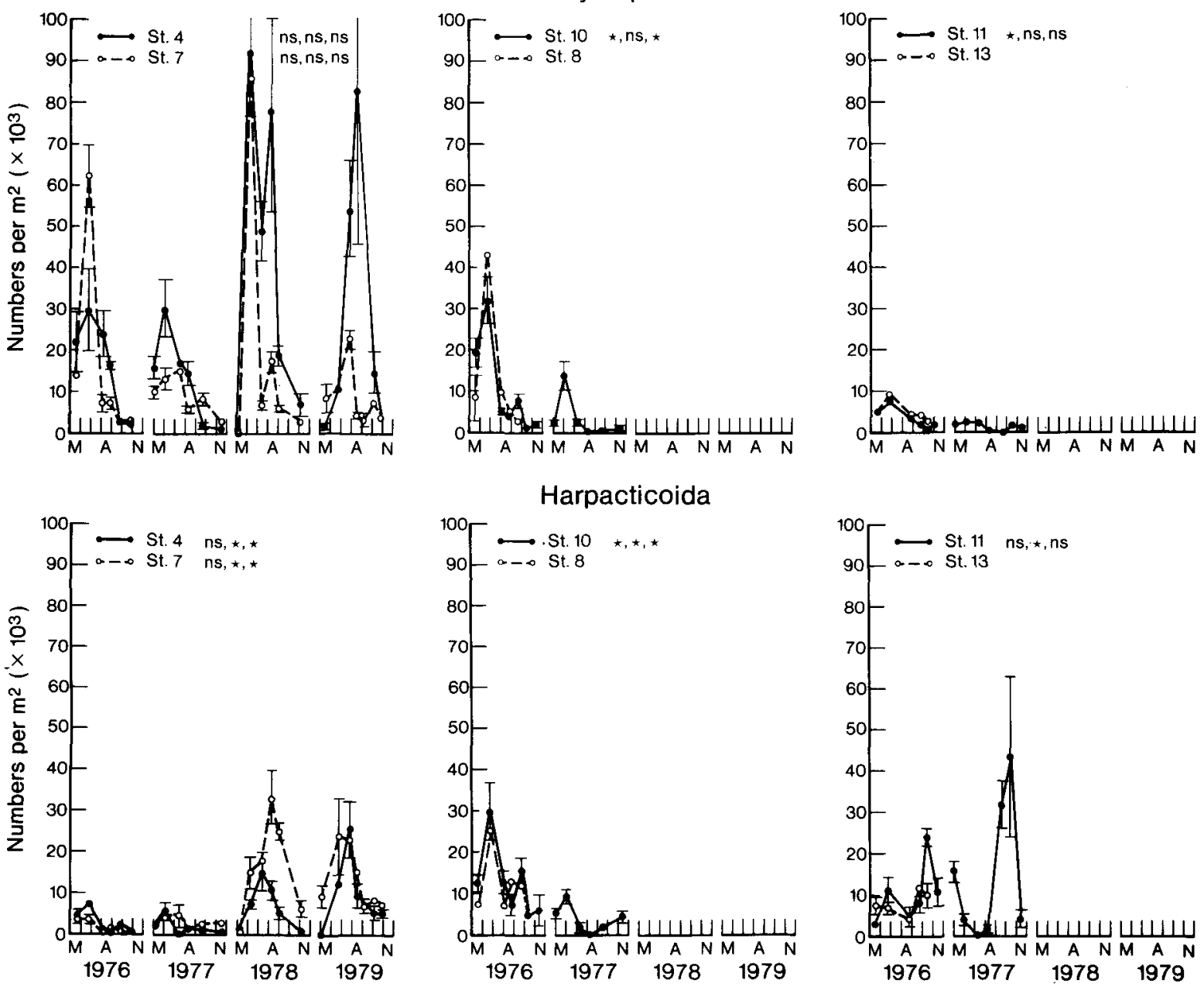

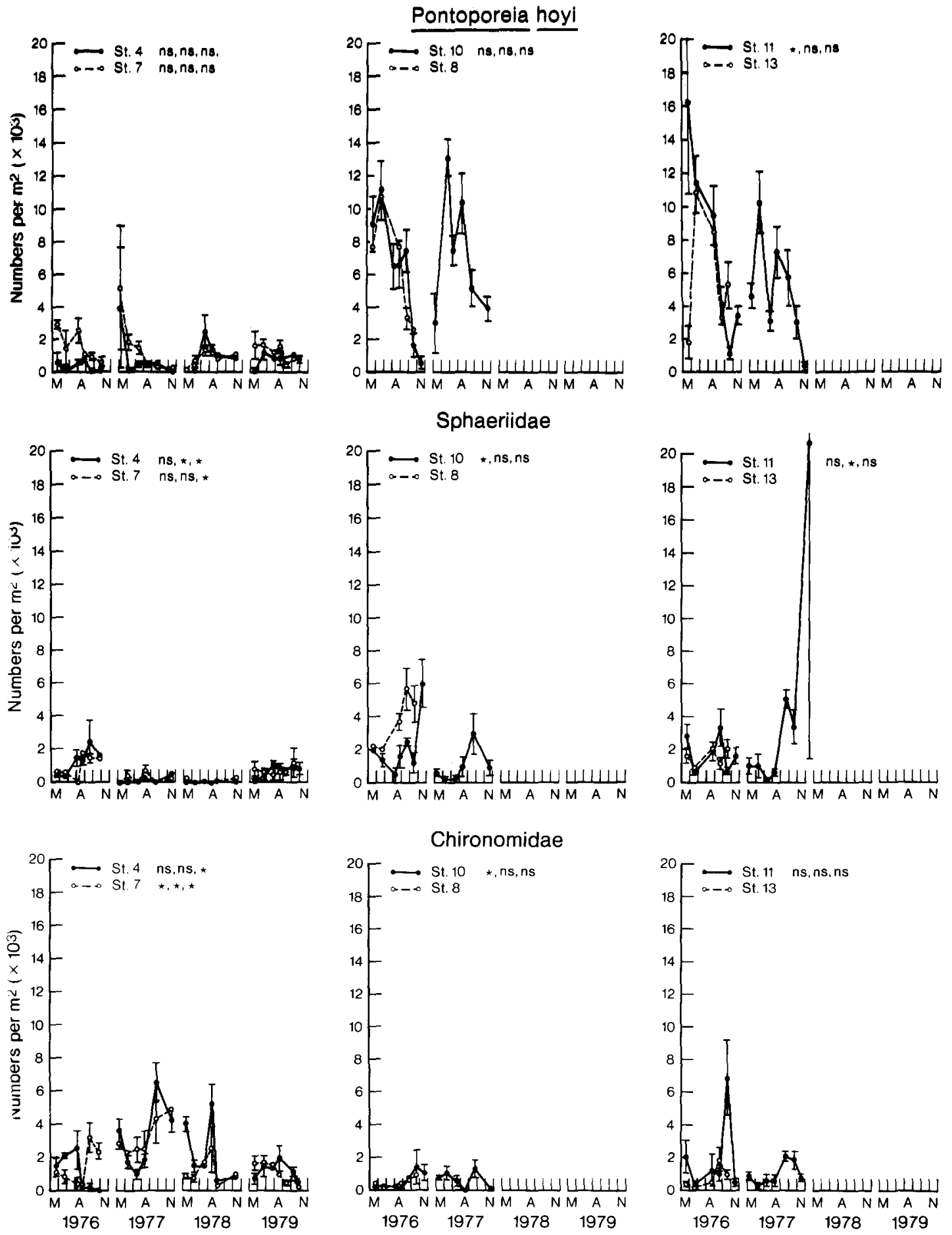
for Naididae. Significant differences between years for the spring, summer, and fall periods were determined by using 

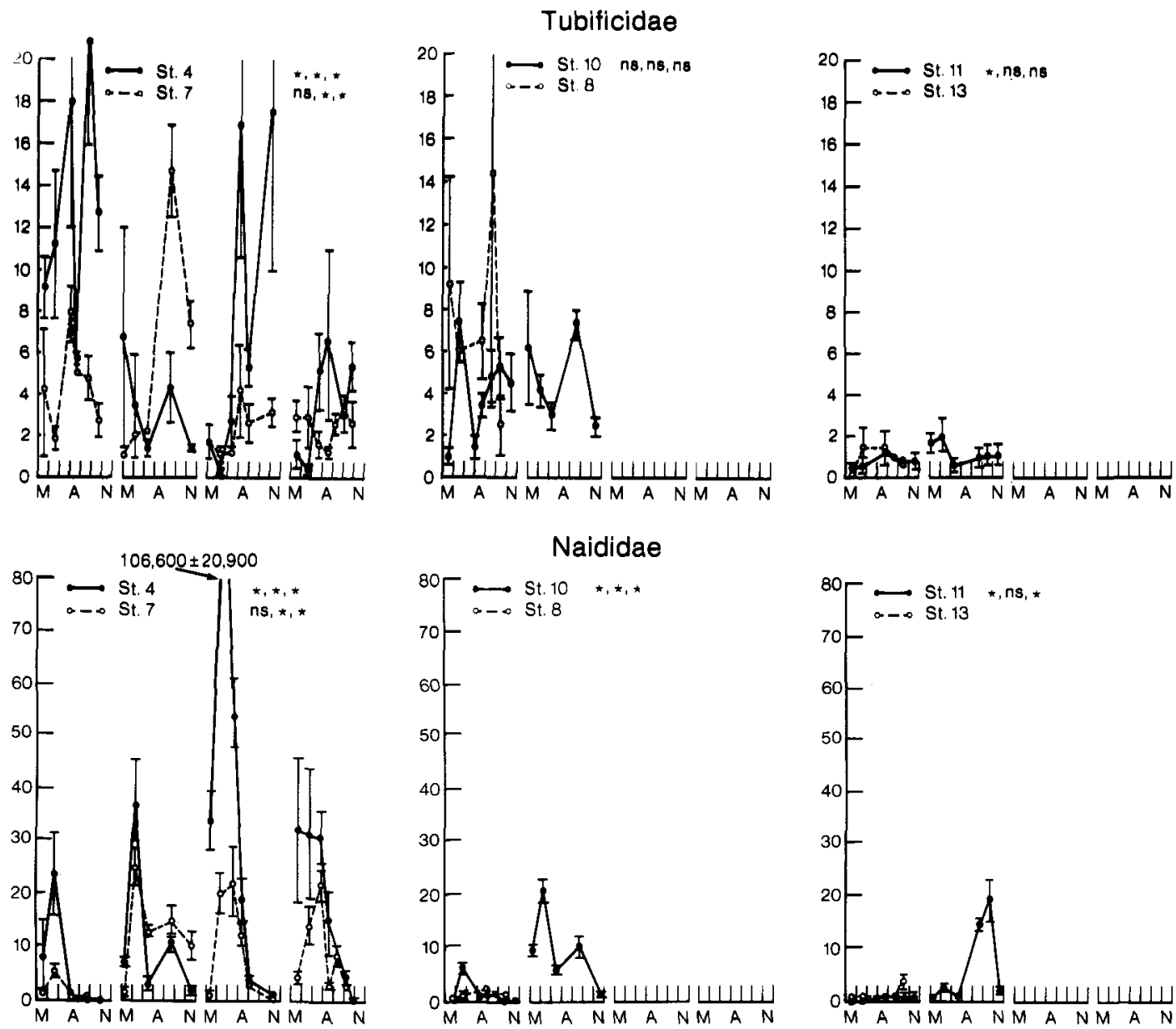

Naididae
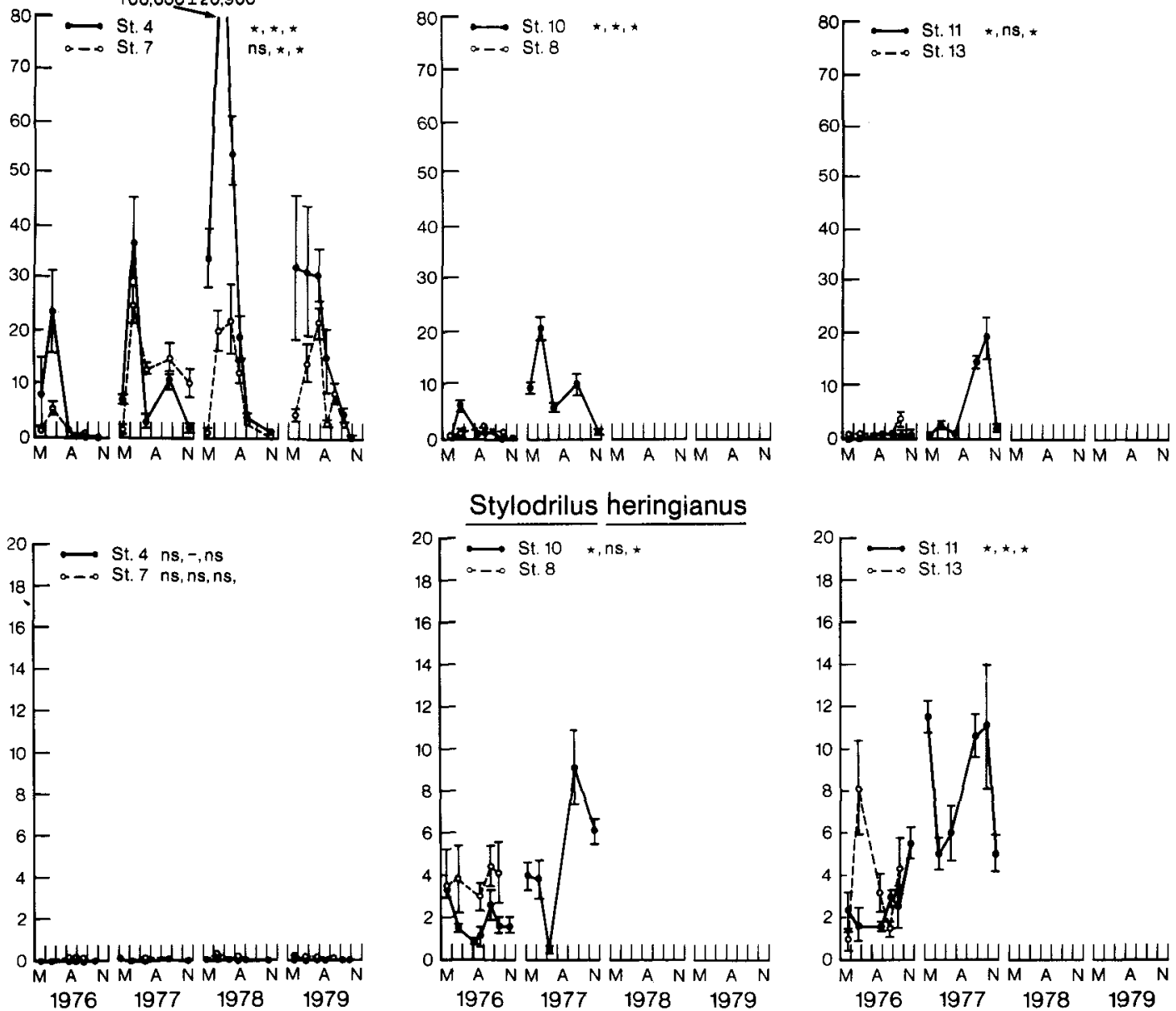

the Kruskal-Wallis test at Stations 4 and 7 and by using the Mann-Whitney test at Stations 10 and 11. All cores at a given station in a given period were treated as separate replicates. $n s=$ not significant, ${ }^{*}=$ significant $(P<0.05)$. 
TABLE 2. Kendall's rank correlation coefficients relating yearly abundances of the major taxa to amounts of surface detritus. Sampling dates were first divided into spring and summer periods (no detritus in fall) and a separate correlation calculated for each period. Analysis includes 4 years of samples at Stations 4 and 7 and two years at Stations 10 and 11. All cores in a given seasonal period $(n)$ were treated as separate replicates. Variation in amounts of detritus between years at Stations 10 and 11 in the summer was insufficient for calculation of a coefficient.

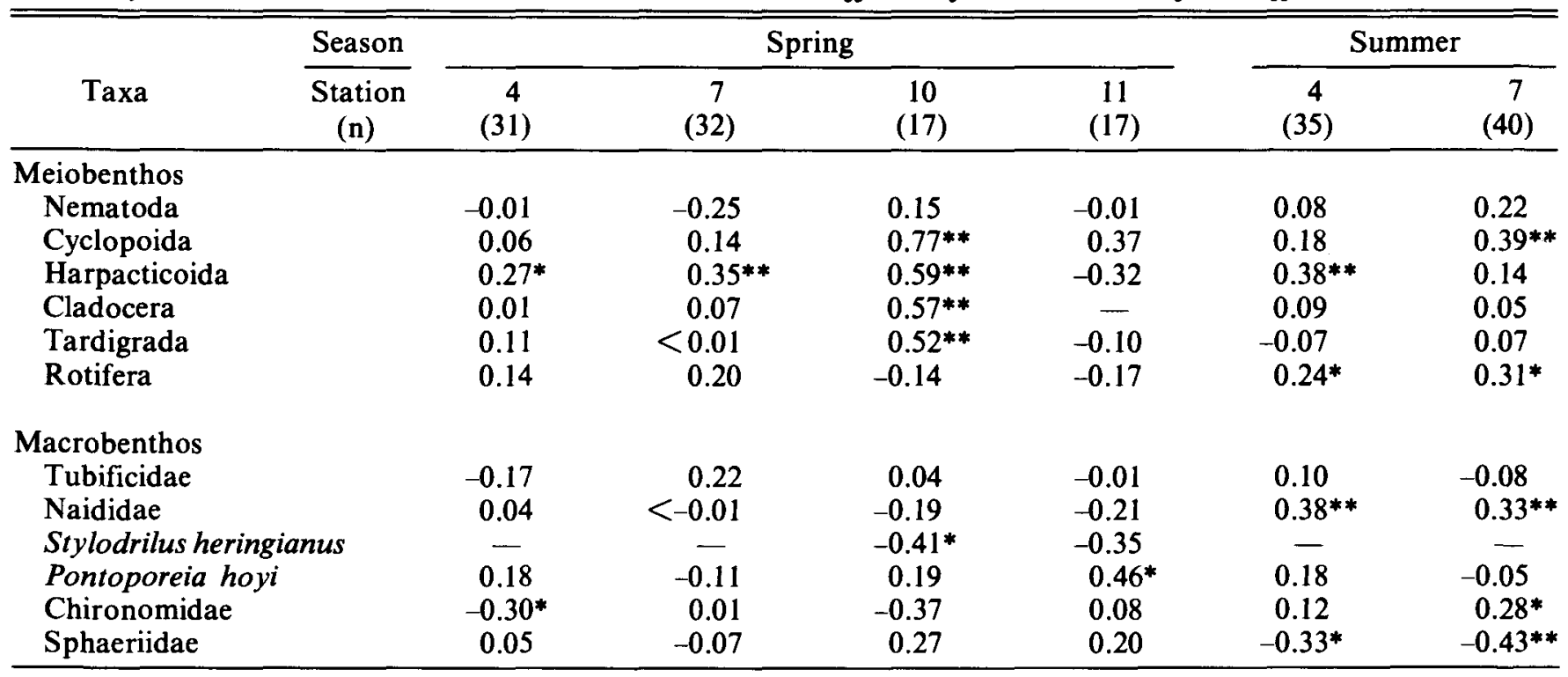

$*$ = significant $(P<0.05)$

** = significant $(P<0.01)$

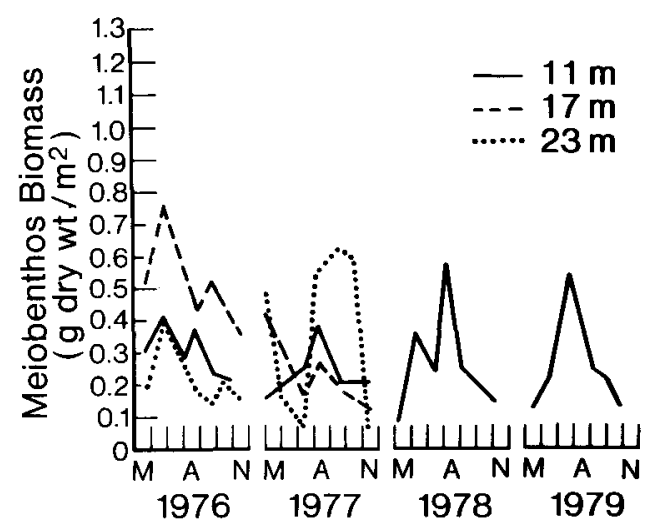

FIG. 5. Mean biomass (dry weight) of the meiobenthos at the 11-, 17-, and 23-m depths on each sampling date.

benthic biomass at $11 \mathrm{~m}$ compared to only $3 \%$ at $23 \mathrm{~m}$.

The relationship between depth and the distribution of the macrobenthos in nearshore Lake Michigan has been detailed previously (Mozley and Garcia 1972, Mozley and Winnell 1975). Macrobenthic distributions in our study area generally agreed with these previous works (Table 5). Of the major macrobenthic taxa, the abundance of Pontoporeia hoyi, Stylodrilus heringianus, and sphaeriids increased with increasing depth, naidids and chironomids were most numerous at $11 \mathrm{~m}$, and tubificids were more abundant at 11 and $17 \mathrm{~m}$ than at $23 \mathrm{~m}$.

Total biomass of the macrobenthos generally increased with increased sampling depth. This can be mainly attributed to Pontoporeia hoyi; both the number and average weight per individual (greater percentage of adults) of this species were greater at the deeper depths.

\section{Macrobenthos:Meiobenthos Ratio}

The overall macrobenthos:meiobenthos biomass ratio was 15:1 and ranged from 5:1 to $45: 1$ on an annual basis (Table 6). The ratio generally increased with increasing depth. This was a result not of a decrease in meiobenthic biomass, but rather of an increase in macrobenthic biomass at the deeper depths (Table 5).

\section{DISCUSSION}

The meiobenthos of other freshwater lakes and of nearshore marine waters has been welldocumented, but little is known about the meiobenthos of the Great Lakes. To put our results in perspective, Table 7 compares the abundance and 
TABLE 3. Kendall's rank correlation coefficients relating abundances of the major taxa and amounts of surface detritus at a given depth in 1976. Sampling dates were divided into spring and summer period (no detritus in fall) and all cores in a given period $(n)$ were treated as separate replicates. Variation between replicates at the 23-m depth was insufficient for calculation of a coefficient.

\begin{tabular}{|c|c|c|c|c|c|}
\hline \multirow[b]{2}{*}{ Taxa } & \multirow{2}{*}{$\begin{array}{c}\text { Season } \\
\begin{array}{c}\text { Depth } \\
\text { (n) }\end{array}\end{array}$} & \multicolumn{2}{|c|}{ Spring } & \multicolumn{2}{|c|}{ Summer } \\
\hline & & $\begin{array}{c}11 \mathrm{~m}^{1} \\
(40)\end{array}$ & $\begin{array}{c}17 \mathrm{~m}^{2} \\
(15)\end{array}$ & $\begin{array}{l}11 \mathrm{~m} \\
(31)\end{array}$ & $\begin{array}{c}17 \mathrm{~m} \\
(16)\end{array}$ \\
\hline \multicolumn{6}{|l|}{ Meiobenthos } \\
\hline Nematoda & & $-0.32 * *$ & 0.17 & 0.20 & 0.20 \\
\hline Cyclopoida & & 0.08 & 0.39 & 0.12 & 0.18 \\
\hline Harpacticoida & & 0.08 & 0.13 & $0.36^{*}$ & 0.23 \\
\hline Cladocera & & 0.23 & 0.39 & $0.44 * *$ & $0.73^{* *}$ \\
\hline Tardigrada & & -0.07 & 0.13 & 0.02 & 0.09 \\
\hline Rotifera & & 0.02 & 0.24 & 0.13 & -0.06 \\
\hline \multicolumn{6}{|l|}{ Macrobenthos } \\
\hline Tubificidae & & 0.06 & 0.16 & 0.22 & $0.46^{*}$ \\
\hline Naididae & & 0.09 & 0.26 & -0.11 & 0.42 \\
\hline Stylodrilus heringianus & & - & -0.01 & - & $0.64^{* *}$ \\
\hline Pontoporeia hoyi & & -0.12 & -0.11 & 0.14 & 0.13 \\
\hline Chironomidae & & 0.17 & -0.17 & -0.17 & 0.24 \\
\hline Sphaeriidae & & -0.02 & -0.15 & 0.20 & $0.45^{*}$ \\
\hline
\end{tabular}

$1=$ Stations $1,4,5,6,7$

$2=$ Stations 8,10

* = significant $(\mathrm{P}<0.05)$

** = significant $(\mathrm{P}<0.01)$

biomass of the meiobenthos in our study area to that found at similar depths in other aquatic environments. Although methods of collection and screen mesh sizes may have differed, some generalized comparisons are appropriate. Clearly, both the abundance and biomass of the meiobenthos in our study area was comparable to that found in other environments. In terms of composition, nematodes accounted for $80 \%$ of all meiobenthic individuals in Lake Michigan compared to 9 to $53 \%$ in other freshwater lakes and to 58 to $95 \%$ in nearshore marine waters. The dominance of nematodes at both our site and in the nearshore marine may be related to similarities in the physical environment at the depths sampled, i.e., sandy substrates, wave turbulence. Nematodes are well-suited for inhabiting well-sorted, interstitial habitats. At similar depths in small, freshwater lakes (as those in Table 7) substrates are much finer and such epibenthic forms as cyclopoids and cladocerans account for a greater percentage of the total meiobenthos.

Our study can be reliably compared to only one other Great Lakes work. Evans and Stewart (1977) gave densities of benthic copepods, cladocerans, and ostracods in an area $125 \mathrm{~km}$ south of our study site. Substrates at the two sites were similar and sampling techniques were comparable. Densities at the $11-\mathrm{m}$ depth in our study (two stations) were compared to densities at the 9-m depth in their study (Table 8). We found fewer cyclopoids, cladocerans, and ostracods but more harpacticoids. Reasons for these differences are unclear and, in fact, may be related to the $2-\mathrm{m}$ difference in sampling depth between the two studies. More likely, however, these differences reflect the varying impact of local inputs to the nearshore areas or perhaps the generally more eutrophic nature of the southern region of the lake. Many cyclopoids (C. vernalis) and cladocerans $(A$. affinis, $E$. lamellatus) are more abundant in areas of the Great Lakes considered eutrophic or mesotrophic (Patalas 1972, Gannon 1972). The response of freshwater harpacticoids to trophic enrichment is not known, but marine forms are generally less abundant in enriched areas (McIntyre 1977).

Potential causes of temporal and spatial variation in both the meiobenthos and macrobenthos in nearshore southeastern Lake Michigan are difficult to define because many factors may interact to affect distributions (Mozley and Garcia 1972, Mozley and Winnell 1975). In addition, such short- 
TABLE 4. Mean annual density and biomass of the major meiobenthic groups at 11, 17, and $23 \mathrm{~m}$ in 1976 and 1977. Density given as numbers per $m^{2} \times 10^{3}$ and biomass (in parentheses) as mg per $m^{2}$. Significant differences in densities at the three depths were determined with the Kruskal-Wallis (K) and median $(M)$ test.

\begin{tabular}{|c|c|c|c|c|c|c|}
\hline \multirow[b]{2}{*}{ Group } & \multirow[b]{2}{*}{ Year } & \multicolumn{3}{|c|}{ Depth (meters) } & \multirow[b]{2}{*}{$\mathbf{K}^{1}$} & \multirow[b]{2}{*}{$\mathbf{M}$} \\
\hline & & 11 & 17 & 23 & & \\
\hline Nematoda & $\begin{array}{r}1976 \\
77\end{array}$ & $\begin{array}{l}188.0(216.7) \\
292.4(148.4)\end{array}$ & $\begin{array}{l}394.7(401.5) \\
196.4(200.5)\end{array}$ & $\begin{array}{l}146.0(168.9) \\
323.1(292.8)\end{array}$ & $\begin{array}{r}* * * \\
\mathrm{~ns}\end{array}$ & $\begin{array}{r}* * * \\
\mathrm{~ns}\end{array}$ \\
\hline Cyclopoida $^{2}$ & $\begin{array}{r}1976 \\
77\end{array}$ & $\begin{array}{c}20.4(53.1) \\
11.7(44.0)\end{array}$ & $\begin{array}{rr}12.4 & (35.7) \\
3.5 & (9.5)\end{array}$ & $\begin{array}{rr}4.5 & (11.3) \\
1.5 & (2.2)\end{array}$ & $\begin{array}{l}* * * \\
* * *\end{array}$ & $\begin{array}{l}* * * \\
* * *\end{array}$ \\
\hline Harpacticoida & $\begin{array}{r}1976 \\
77\end{array}$ & $\begin{array}{ll}2.9 & (7.7) \\
2.6 & (5.4)\end{array}$ & $\begin{array}{rr}12.8 & (29.8) \\
4.1 & (9.1)\end{array}$ & $\begin{array}{rr}9.1 & (13.3) \\
14.5 & (23.6)\end{array}$ & $\begin{array}{l}* * * \\
* * *\end{array}$ & $\begin{array}{c}* * * \\
\mathrm{~ns}\end{array}$ \\
\hline Cladocera & $\begin{array}{r}1976 \\
77\end{array}$ & $\begin{array}{ll}5.4 & (29.4) \\
5.1 & (33.8)\end{array}$ & $\begin{array}{lr}2.6 & (11.9) \\
0.9 & (6.3)\end{array}$ & $\begin{array}{ll}0.2 & (0.1) \\
0 & (0)\end{array}$ & $\begin{array}{l}* * * \\
* * *\end{array}$ & $\begin{array}{l}* * * \\
* * *\end{array}$ \\
\hline Tardigrada & $\begin{array}{r}1976 \\
77\end{array}$ & $\begin{array}{ll}4.3 & (1.3) \\
1.1 & (0.3)\end{array}$ & $\begin{array}{rr}149.4 & (44.8) \\
14.8 & (4.4)\end{array}$ & $\begin{aligned} 28.0 & (8.4) \\
3.5 & (1.1)\end{aligned}$ & *** & $\begin{array}{l}* * * \\
* *\end{array}$ \\
\hline Rotifera & $\begin{array}{r}1976 \\
77\end{array}$ & $\begin{array}{ll}6.9 & (1.4) \\
4.7 & (0.9)\end{array}$ & $\begin{array}{l}(3.4) \\
(1.4)\end{array}$ & $\begin{aligned} 14.7 & (2.9) \\
5.2 & (1.0)\end{aligned}$ & $\begin{array}{c}* * * \\
\mathrm{~ns}\end{array}$ & $\begin{array}{l}\text { ns } \\
\text { ns }\end{array}$ \\
\hline Ostracoda & $\begin{array}{r}1976 \\
77\end{array}$ & $\begin{array}{lr}0.5 & (10.9) \\
0.3 & (6.8)\end{array}$ & $\begin{array}{ll}0.4 & (7.8) \\
0.1 & (1.7)\end{array}$ & $\begin{array}{rr}0.9 & (1.9) \\
1.4 & (29.2)\end{array}$ & *** & $\begin{array}{l}* * \\
\mathrm{~ns}\end{array}$ \\
\hline Turbellaria & $\begin{array}{r}1976 \\
77\end{array}$ & $\begin{array}{ll}0.8 & (2.8) \\
0.5 & (1.6) \\
\end{array}$ & $\begin{array}{ll}1.0 & (3.6) \\
1.3 & (4.7) \\
\end{array}$ & $\begin{array}{ll}0.5 & (1.8) \\
0.5 & (1.8) \\
\end{array}$ & $\begin{array}{l}\text { ns } \\
\text { ns }\end{array}$ & $\begin{array}{l}\text { ns } \\
\text { ns }\end{array}$ \\
\hline Total & $\begin{array}{r}1976 \\
77\end{array}$ & $\begin{array}{l}229.2(323.3) \\
318.4(241.2)\end{array}$ & $\begin{array}{l}590.3(538.5) \\
228.1(237.6)\end{array}$ & $\begin{array}{l}203.9(208.5) \\
349.7(351.7)\end{array}$ & $\begin{array}{l}* * * \\
\text { ns }\end{array}$ & $\begin{array}{r}* * * \\
\text { ns }\end{array}$ \\
\hline
\end{tabular}

$1_{*}=$ significant $(\mathrm{P}<0.05) ; * *$ significant $(\mathrm{P}<0.01) ; * *=$ significant $(\mathrm{P}<0.001)$.

${ }^{2}$ Includes Eurytemora affinis.

term events as storms, varying currents, etc. may re-distribute the benthos in ways seemingly unrelated to any physical features of the environment. However, at least some of the differences in abundance between years at the same station and between stations at the same depth appeared related to variations in the amount of surface detritus. This material had a higher organic content than the sandy substrate (Nalepa and Robertson $1981 \mathrm{~b}$ ) and may have served as a source of food for the benthos (either directly or indirectly through associated bacteria). Depending on the particular season and station, abundances of several groups were significantly related to this material (Tables 2 and 3 ). Of course, any relationship between the abundance of a given group and the detritus will vary depending on the group's vertical distribution, feeding mode, and life cycle relative to when the detritus was present.

For the meiobenthos, most significant correlations to the detritus were positive. The groups most often associated with the detritus were cyclopoids, cladocerans, harpacticoids, and rotifers. All of these groups are found mainly in the upper $1 \mathrm{~cm}$ of substrate (Nalepa and Robertson 1981b) and thus would be the most likely to respond to a surface food source. In addition, the dominant taxa in these groups have feeding modes well-suited for utilizing this material. Ilyocryptus and Canthocamptus are ooze browsers (e.g., Evans and Stewart 1977), and Eurycercus and most benthic rotifers are seston feeders (Frey 1971, Pennak 1978). The cyclopoids Cyclops vernalis and Cyclops bicuspidatus thomasi are mainly carnivores (McQueen 1969, Anderson 1970), so their positive association with the detritus may be related to the greater number of prey organisms found in this material.

Nematode and tardigrade abundances were not as strongly related to detrital amounts as the other meiobenthic groups - only a single significant correlation occurred in each group (Tables 2 and 3). Both groups are found deeper in the sediments (Nalepa and Robertson 1981b) and may not be as responsive to a surface food layer. While yearly abundances of tardigrades at Station 10 were positively correlated to detrital amounts (Table 3), 
TABLE 5. Mean annual density and biomass of the major macrobenthic groups at 11, 17, and $23 \mathrm{~m}$ in 1976 and 1977. Density given as numbers per $\mathrm{m}^{2} \times 10^{3}$ and biomass (in parentheses) as mg per $\mathrm{m}^{2}$. Significant differences in densities at the three depths were determined with the Kruskal-Wallis (K) and median (M) tests.

\begin{tabular}{|c|c|c|c|c|c|c|c|c|c|}
\hline \multirow[b]{2}{*}{ Taxa } & \multirow[b]{2}{*}{ Year } & \multicolumn{6}{|c|}{ Depth (meters) } & \multirow[b]{2}{*}{$\mathbf{K}^{1}$} & \multirow[b]{2}{*}{$\mathbf{M}$} \\
\hline & & \multicolumn{2}{|c|}{11} & \multicolumn{2}{|c|}{17} & \multicolumn{2}{|c|}{23} & & \\
\hline Oligochaeta & $\begin{array}{r}1976 \\
77\end{array}$ & \multicolumn{2}{|c|}{$\begin{array}{l}(2,437.5) \\
(1,004.6)\end{array}$} & \multicolumn{2}{|c|}{$\begin{array}{l}(2,474.3) \\
(1,990.9)\end{array}$} & \multicolumn{2}{|c|}{$\begin{array}{l}(1,420.3) \\
(2,593.1)\end{array}$} & & \\
\hline Enchytraeidae & $\begin{array}{r}1976 \\
77\end{array}$ & $\begin{array}{l}0.1 \\
0.3\end{array}$ & $-^{2}$ & $\begin{array}{l}0.2 \\
1.9\end{array}$ & - & $\begin{array}{l}2.9 \\
2.7\end{array}$ & - & $\begin{array}{l}* * * \\
* *\end{array}$ & $\underset{*}{\mathrm{~ns}}$ \\
\hline Stylodrilus heringianus & $\begin{array}{r}1976 \\
77\end{array}$ & $\begin{array}{l}<0.1 \\
<0.1\end{array}$ & - & $\begin{array}{l}2.8 \\
4.7\end{array}$ & - & $\begin{array}{l}3.2 \\
8.4\end{array}$ & - & $\begin{array}{l}* * * \\
* * *\end{array}$ & $\begin{array}{l}* * * \\
* * *\end{array}$ \\
\hline Naididae & $\begin{array}{r}1976 \\
77\end{array}$ & $\begin{array}{r}5.2 \\
12.8\end{array}$ & - & $\begin{array}{l}1.8 \\
9.4\end{array}$ & - & $\begin{array}{l}1.2 \\
6.6\end{array}$ & - & $\begin{array}{c}\mathrm{ns} \\
*\end{array}$ & $\begin{array}{l}\text { ns } \\
\text { ns }\end{array}$ \\
\hline Tubificidae & $\begin{array}{r}1976 \\
77\end{array}$ & $\begin{array}{l}8.4 \\
4.5\end{array}$ & - & $\begin{array}{l}5.4 \\
4.7\end{array}$ & - & $\begin{array}{l}1.0 \\
1.3\end{array}$ & - & $\begin{array}{l}* * * \\
* * *\end{array}$ & $\begin{array}{l}* * * \\
* * *\end{array}$ \\
\hline Amphipoda & $\begin{array}{r}1976 \\
77\end{array}$ & $\begin{array}{l}1.8 \\
1.2\end{array}$ & $\begin{array}{r}(1,056.6) \\
(374.7)\end{array}$ & $\begin{array}{l}6.4 \\
7.0\end{array}$ & $\begin{array}{l}(4,268.6) \\
(2,757.4)\end{array}$ & $\begin{array}{l}7.3( \\
4.9(\end{array}$ & $\begin{array}{l}6,321.6) \\
5,844.7)\end{array}$ & $\begin{array}{l}* * * \\
* * *\end{array}$ & $\begin{array}{l}* * * \\
* * *\end{array}$ \\
\hline Chironomidae & $\begin{array}{r}1976 \\
77\end{array}$ & $\begin{array}{l}1.7 \\
3.1\end{array}$ & $\begin{array}{l}(121.6) \\
(235.0)\end{array}$ & $\begin{array}{l}0.5 \\
0.7\end{array}$ & $\begin{array}{l}(19.2) \\
(50.5)\end{array}$ & $\begin{array}{l}1.4 \\
1.0\end{array}$ & $\begin{array}{l}(97.4) \\
(75.3)\end{array}$ & $\begin{array}{l}* * * \\
* * *\end{array}$ & $\begin{array}{l}* * * \\
* * *\end{array}$ \\
\hline Sphaeriidae & $\begin{array}{r}1976 \\
77\end{array}$ & $\begin{array}{l}1.1 \\
0.2\end{array}$ & $\begin{array}{r}(136.4) \\
(37.9)\end{array}$ & $\begin{array}{l}2.9 \\
0.8\end{array}$ & $\begin{array}{l}(435.4) \\
(246.7)\end{array}$ & $\begin{array}{l}1.8 \\
1.6\end{array}$ & $\begin{array}{l}(445.0) \\
(833.6)\end{array}$ & $\begin{array}{l}* * * \\
* * *\end{array}$ & $\begin{array}{c}* * * \\
\mathrm{~ns}\end{array}$ \\
\hline Gastropoda & $\begin{array}{r}1976 \\
77\end{array}$ & $\begin{array}{l}0.4 \\
0.1\end{array}$ & $\begin{array}{r}(263.5) \\
(84.9)\end{array}$ & $\begin{array}{l}0.4 \\
0.1\end{array}$ & $\begin{array}{r}(236.6) \\
(65.1)\end{array}$ & $\begin{array}{c}<0.1 \\
0\end{array}$ & $\begin{array}{c}(38.8) \\
(0)\end{array}$ & $\begin{array}{l}* * \\
\mathrm{~ns}\end{array}$ & $\begin{array}{l}\text { ns } \\
\text { ns }\end{array}$ \\
\hline Hirudinea & $\begin{array}{r}1976 \\
77\end{array}$ & $\begin{array}{c}<0.1 \\
0 \\
\end{array}$ & $\begin{array}{l}(7.1) \\
(0) \\
\end{array}$ & $\begin{array}{l}0.2 \\
0.1 \\
\end{array}$ & $\begin{array}{r}(137.9) \\
(70.3) \\
\end{array}$ & $\begin{array}{r}<0.1 \\
0.1 \\
\end{array}$ & $\begin{array}{l}(16.7) \\
(36.4) \\
\end{array}$ & $\begin{array}{l}\text { ns } \\
\text { ns }\end{array}$ & $\begin{array}{l}\text { ns } \\
\text { ns }\end{array}$ \\
\hline Total & $\begin{array}{r}1976 \\
77\end{array}$ & $\begin{array}{l}18.8 \\
22.8\end{array}$ & $\begin{array}{l}(4,022.7) \\
(1,737.1)\end{array}$ & $\begin{array}{l}20.6 \\
29.4\end{array}$ & $\begin{array}{l}(7,572.0) \\
(5,180.9)\end{array}$ & $\begin{array}{l}18.8( \\
26.6(\end{array}$ & $\begin{array}{l}8,339.8) \\
9,383.1)\end{array}$ & $\begin{array}{c}* \\
\text { ns }\end{array}$ & $\begin{array}{r}* * * \\
\mathrm{~ns}\end{array}$ \\
\hline
\end{tabular}

$1^{*}=$ significant $(\mathrm{P}<0.05) ;{ }^{* *}=$ significant $(\mathrm{P}<0.01) ;{ }^{* *}=$ significant $(\mathrm{P}<0.001)$.

2 = Biomass of individual oligochaete taxa not determined.

TABLE 6. Mean and range of the macrobenthos:meiobenthos biomass ratio at each depth for each year.

\begin{tabular}{ccccc}
\hline \hline & \multicolumn{4}{c}{ Depth (meters) } \\
\cline { 2 - 5 } Year & 11 & 17 & 23 \\
\hline 1976 & $12: 1(10-19: 1)$ & $14: 1(10-20: 1)$ & $37: 1(28-53: 1)$ \\
1977 & $8: 1$ & $(6-12: 1)$ & $21: 1(10-73: 1)$ & $45: 1(15-118: 1)$ \\
1978 & $5: 1$ & $(1-14: 1)$ & - & - \\
1979 & $5: 1$ & $(3-13: 1)$ & - & - \\
\hline
\end{tabular}

nematode abundances at the $11-\mathrm{m}$ stations in spring 1976 were negatively correlated to detrital amounts (Table 4). Reasons for the negative correlation in nematodes are not clear. Conceivably, a detrital layer may have clogged interstitial pore spaces, thus having an adverse effect on this group. However, nematode densities did not decline in years when great amounts of detritus occurred, as at Station 4 in 1978. Since nematode feeding habits are highly species dependent (Wieser 1960), perhaps further insight into the relation between nematode abundances and amounts of detritus would have been achieved if this group were identified to the species level.

For the macrobenthos, abundances of naidids and tubificids tended to be positively correlated to the detritus, but inconsistencies were apparent in the other groups. For instance, at the 17-m depth in 1976, abundances of Stylodrilus heringianus were positively correlated to detrital amounts; more detritus occurred at Station 8 than at Station 10 and corresponding densities of $S$. heringianus were greater at the former station (Fig. 4). However, annual abundances of $S$. heringianus were negatively correlated with detrital amounts; abundances were greater at Station 10 in 1977 than in 1976, 
TABLE 7. Mean density and biomass (dry wt.) of the meiobenthos from various locations. The studies given are those from sites with depths and/or with sediments similar to our Lake Michigan work.

\begin{tabular}{|c|c|c|c|c|c|c|c|}
\hline $\begin{array}{c}\text { Study } \\
\text { Site }\end{array}$ & $\begin{array}{c}\text { Depth } \\
\text { (meters) }\end{array}$ & Sediment Type & $\begin{array}{l}\text { Mesh size } \\
\text { used } \\
(\mu \mathrm{m})\end{array}$ & $\begin{array}{c}\text { Number of } \\
\text { Nematodes } \\
\left(\text { per } m^{2} \times 10^{3}\right)\end{array}$ & $\begin{array}{c}\text { Number of } \\
\text { Meiobenthos } \\
\left(\text { per } \mathrm{m}^{2} \times 10^{3}\right)\end{array}$ & $\begin{array}{l}\text { Biomass of } \\
\text { Meiobenthos } \\
\left(\mathrm{g} \text { per } \mathrm{m}^{2}\right)\end{array}$ & Reference \\
\hline \multicolumn{8}{|l|}{ Freshwater Lakes } \\
\hline $\begin{array}{l}\text { Lake Malaren, } \\
\text { Sweden }\end{array}$ & 32 & detritus, silt & 60 & 5 & 54 & - & Milbrink (1969) \\
\hline $\begin{array}{l}\text { Lake Paijanne, } \\
\text { Finland }\end{array}$ & $30-42$ & detritus, clay & 100 & 12 & 80 & - & $\begin{array}{l}\text { Sarkka and Paasivirta } \\
\text { (1972) }\end{array}$ \\
\hline $\begin{array}{l}\text { Lake Paajarvi, } \\
\text { Finland }\end{array}$ & $13-25$ & ooze, clay & 100 & 112 & 178 & .23 & $\begin{array}{l}\text { Holopainen and } \\
\text { Paasivirta (1977) }\end{array}$ \\
\hline Lake Michigan & $11-23$ & fine-coarse sand & 45 & 245 & 303 & .32 & Present Study \\
\hline $\begin{array}{l}\text { Mountain lakes, } \\
\text { Canada }\end{array}$ & $8-16$ & - & 45 & 202 & 380 & 1.33 & $\begin{array}{l}\text { Anderson and DeHenau } \\
\text { (1980) }\end{array}$ \\
\hline \multicolumn{8}{|l|}{ Nearshore Marine } \\
\hline $\begin{array}{l}\text { Helgoland Bay, } \\
\text { North Seea }\end{array}$ & $12-30$ & medium-coarse sand & - & - & 127 & .05 & Stripp (1969) \\
\hline English Channel & 45 & sand, mud & 100 & 83 & 146 & .23 & Mare (1942) \\
\hline $\begin{array}{l}\text { Buzzards Bay, } \\
\text { Mass. }\end{array}$ & $12-30$ & sand & Unscreened & 355 & 370 & .28 & Wieser $(1960)$ \\
\hline Kiel Bay & $7.5-12$ & fine-coarse sand & - & 322 & 503 & - & Scheibel (1973) \\
\hline $\begin{array}{l}\text { Off French Coast, } \\
\text { Mediterranean }\end{array}$ & $2-25$ & fine sand & 88 & - & 537 & .44 & Guille and Soyer (1974) \\
\hline $\begin{array}{l}\text { Off Mass., } \\
\text { Atlantic }\end{array}$ & $40-58$ & sand, sandy gravel & 74 & 544 & 663 & .66 & $\begin{array}{l}\text { Wigley and McIntyre } \\
(1964)\end{array}$ \\
\hline Baltic Sea & $9-23$ & sand & 7 & 1,500 & 2,223 & 1.08 & $\begin{array}{l}\text { Ankar and Elmgren } \\
(1976)\end{array}$ \\
\hline
\end{tabular}

${ }^{1}$ About $30 \%$ of all nematodes pass a $106-\mu \mathrm{m}$ screen to be retained on a $45-\mu \mathrm{m}$ screen (Nalepa and Robertson 198Ia). Thus, nematode estimates in studies using a mesh size greater than $45-\mu \mathrm{m}$ are somewhat underestimated.

${ }^{2}$ Dry weight assumed to be $20 \%$ of wet weight.

$T A B L E$ 8. $A$ comparison between mean densities reported by Evans and Stewart (1977) at $9 \mathrm{~m}$ and mean densities $\pm S E$ found in this study at $11 \mathrm{~m}$ (two stations). The means in this study were computed from cores collected between mid-July and early A ugust 1976-79 to compare to the late July sampling date of Evans and Stewart in 1974. Densities given as numbers per $m^{2} \times$ $10^{3}$.

\begin{tabular}{|c|c|c|c|}
\hline & \multirow{2}{*}{$\begin{array}{c}\text { Evans and } \\
\text { Stewart }\end{array}$} & \multicolumn{2}{|c|}{ This Study } \\
\hline & & Station 4 & Station 7 \\
\hline Cyclopoida $^{1}$ & 48.6 & $36.6 \pm 21.6$ & $12.7 \pm 3.1$ \\
\hline Harpacticoida & 1.2 & $9.3 \pm 3.0$ & $13.7 \pm 4.1$ \\
\hline Cladocera $^{2}$ & 29.8 & $17.6 \pm 9.7$ & $8.3 \pm 2.4$ \\
\hline Ostracoda & 2.9 & $0.3 \pm 0.2$ & $0.8 \pm 0.5$ \\
\hline
\end{tabular}

${ }^{1}$ Includes Eurytemora affinis.

${ }^{2}$ Includes Chydorus sphaericus.

even though amounts of detritus were less in the former year. Similar inconsistencies (both positive and negative correlations) were apparent also for sphaeriids and chironomids.

An important consideration in relating yearly differences in abundance to yearly differences in amounts of detritus is the relative generation times of the various groups. Many meiobenthic groups as well as naidids have short generation times and, thus, populations are capable of rapidly responding to any changes in detrital amounts. For example, the great density peaks of cyclopoids, cladocerans, and naidids at Station 4 in the summer of 1978 coincided with the presence of a thick detrital patch at this station throughout the summer of 1978 . On the other hand, many macrobenthic groups have longer generation times, and the response to yearly changes in detritus would not be as discernible. For example, tubificids have a 1 year life cycle at the sampled depths, as judged by the high percentage of sexually mature individuals in the spring and an increase of smaller individuals in the summer (Nalepa and Robertson 1981a). Thus, numbers of tubificids were actually highest in the summer when detrital amounts were minimal. Similar life cycle patterns may account for the negative correlations found in $S$. heringianus and sphaeriids.

Depth distributions of the meiobenthos are not as readily interpreted in terms of differences in available food, for other factors such as water 
temperatures, substrate stability, and substrate type may also have played a role. Amounts of potential food declined with increased sampling depth. This was evident from the progressive decline in amounts of detritus at the 11-, 17-, and 23-m depths (Fig. 2). Also, in an area just north of our study area, Stevenson and Stoermer (1981) found that benthic algal densities were greater at 9 to $15 \mathrm{~m}$ than at 22 to $27 \mathrm{~m}$. Benthic algae are a potential food source for many meiobenthic forms (Coull 1973). Despite these indications of a decline in available food, the only meiobenthic groups that declined in abundance with increased sampling depth were cyclopoids and cladocerans. The decline in these two groups is in apparent agreement with the conclusions of Evans and Stewart (1977); they found more cyclopoids and cladocerans at $9 \mathrm{~m}$ than at $6 \mathrm{~m}$, and attributed this difference to more food (in form of detritus) at the former depth. However, at least in our study, water temperatures may also have had an effect. Although bottom temperatures fluctuated broadly in the summer, average temperatures were higher at the shallower depth. Greater densities of both cyclopoids and cladocerans are often found in areas with higher mean temperatures (Patalas 1969, Carter 1969, Carter and Watson 1977).

Other meiobenthic groups were actually more abundant at either 17 or $23 \mathrm{~m}$ than at $11 \mathrm{~m}$ (harpacticoids, tardigrades, ostracods). These groups may prefer the colder but more stable temperatures at these depths, or, since they are more restricted to the sediments than cyclopoids and cladocerans, may prefer depths where the sediments are less influenced by wave action. Substrate type may also have had an influence on distributions. While fine sand occurred at 11 and $17 \mathrm{~m}$, coarse sand was dominant at $23 \mathrm{~m}$. The greater abundance of the harpacticoid Bryocamptus nivalis and ostracods at $23 \mathrm{~m}$ may indicate a preference for coarser substrates by these forms. Abundances of nematodes and rotifers were similar at 11,17 , and $23 \mathrm{~m}$, despite all the physical differences noted between the three depths.

The macrobenthos:meiobenthos biomass ratio in this study (5:1 to 45:1) is generally higher than the 2-3:1 ratio reported from other freshwater lakes (Holopainen and Paasivirta 1977, Anderson and DeHenau 1980). This is not a result of lower meiobenthic standing stocks in Lake Michigan, but rather to greater macrobenthic standing stocks. Mean biomass of the macrobenthos at our site was $4.7 \mathrm{~g} / \mathrm{m}^{2}$, compared to a maxmimum of about 1.5 $\mathrm{g} / \mathrm{m}^{2}$ in these other freshwater lakes. Ratios in nearshore marine waters range from $12: 1$ to $90: 1$ (Stripp 1969, Wigley and McIntyre 1964, and others).

As often noted, the meiobenthos plays a more important role in the dynamics of benthic systems than indicated by quantitative comparisons with the macrobenthos. It has been suggested that turnover rates for the meiobenthos are three to five times greater than for the macrobenthos, and metabolic rates are five times greater (Gerlach 1971 and 1978, McIntyre 1969). Production estimates of the macro- and meiobenthos will not be given here, but a comparison of estimated metabolic rates of the dominant group in each category illustrates the relative importance of the meiobenthos relative to the macrobenthos. During the 4-year sampling period, nematodes accounted for $56 \%$ of the meiobenthic biomass, and oligochaetes (Mostly tubificids) accounted for $56 \%$ of the macrobenthic biomass at the $11-\mathrm{m}$ depth. Since the average weight of a nematode was $0.9 \mu \mathrm{g}$, we estimated a nematode respiration rate of about $2.0 \mu \mathrm{L} / \mathrm{mg}$ dry wt $/ \mathrm{hr}$ at $20^{\circ} \mathrm{C}$ (Wieser and Kanwisher 1961, Dye et al. 1978). In comparison, the average weight of a tubificid was about $0.37 \mathrm{mg}$ (as calculated from 1978-79 samples). The respiration rate of tubificids was estimated at about $0.50 \mu \mathrm{L} / \mathrm{mg}$ dry wt/hr at $20^{\circ} \mathrm{C}$ (Brinkhurst 1972). The metabolic rate of nematodes was thus about four times the metabolic rate of tubificids. If this difference in comparative metabolic rate is true for the remainder of the various meio- and macrobenthic groups, the flow of materials through the meiobenthos at the $11-\mathrm{m}$ depth would be between 33 and $80 \%$ of the flow through the macrobenthos on an annual basis. This indicates that studies on organic utilization or energy flow through nearshore benthic communities in the Great Lakes (c.f. Johnson and Brinkhurst 1971), at least at the shallower depths, should certainly include the meiobenthos.

\section{ACKNOWLEDGMENTS}

We thank R. L. Chambers and S. Congdon for their diving assistance, P. Szymusiak for counting and picking, and the crew of the R/V Shenehon for their help and cooperation during field operations. The review of W. S. Gardner and the comments and statistical insights of $\mathrm{M}$. J. McCormick are appreciated. We also thank the two Journal referees, S. C. Mozley and D. R. Barton, for their constructive reviews of the manuscript. We are 
especially grateful to A. Robertson for his comments and many helpful suggestions. GLERL contribution no. 328 .

\section{REFERENCES}

Anderson, R. S. 1970. Predator-prey relationships and predation rates for crustacean zooplankters from some lakes in western Canada. Can. J. Zool. 48:12291240.

and DeHenau, A. M. 1980. An assessment of the meiobenthos from nine mountain lakes in western Canada. Hydrobiologia 70:257-264.

Ankar, S., and Elmgren, R. 1976. The benthic macroand meiofauna of the Asko-Landsort area (northern Baltic proper): A stratified random sampling survey. Contr. Asko Laboratory 11:1-115.

Brinkhurst, R. O. 1972. The role of sludge worms in entrophication. U.S. Environmental Protection Agency, Ecological Research Services, EPA-R3-72004.

Carter, J. C. H. 1969. Life cycles of Limnocalanus macrurus and Senecella calanoides, and seasonal abundance and vertical distributions of various planktonic copepods in Parry Sound, Georgian Bay. J. Fish. Res. Board Can. 26:2543-2560.

and Watson, N. H. F. 1977. Seasonal and horizontal distributions of planktonic crustacea in Georgian Bay and North Channel, 1974. J. Great Lakes Res. 3:113-122.

Chambers, R. L., and Eadie, B. J. 1980. Nearshore chemistry in the vicinity of the Grand River, Michigan. NOAA Technical Memorandum ERL GLERL-28. Great Lakes Environmental Research Laboratory, Ann Arbor, Michigan.

Conover, W. J. 1971. Practical Nonparametric Statistics. New York: John Wiley and Sons, Inc.

Cook, D. G. 1975. A preliminary report on the benthic macroinvertebrates of Lake Superior. Fish. Res. Board Can., Fish. Mar. Serv. Tech. Rept. 572.

Coull, B. C. 1973. Estuarine meiofauna: review, trophic relationships and microbial interactions. In Estuarine Microbial Ecology, ed. L. H. Stevenson and R. R. Colwells. Columbia, S. C.: Univ. S. Carolina Press.

Cullen, D. J. 1973. Bioturbation of superficial marine sediments by interstitial meiobenthos. Nature 242: 323-324.

Dye, A. H., Erasmus, T., and Furstenburg, J. P. 1978. An ecophysiological study of the meiofauna of the Swartkops Estuary. 3. Partition of benthic oxygen consumption and the relative importance of the meiofauna. Zool. Africa 13::187-199.

Eadie, B. J., Chambers, R. L., Malczyk, J., and Langston, A. 1978. Effect of Grand River spring runoff on Lake Michigan. International Joint Commission, Windsor, Ontario.

Evans, M. S., and Stewart, J. A. 1977. Epibenthic and benthic microcrustaceans (copepods, cladocerans, ostracods) from a nearshore area in southeastern Lake Michigan. Limnol. Oceanogr. 22:1059-1066.

Frey, D. G. 1971. Worldwide distribution and ecology of Eurycerus and Saycia (Cladocera). Limnol. Oceanogr. 16:254-308.

Gannon, J. 1972. A contribution to the ecology of plankton Crustacea of Lake Michigan and Green Bay. Ph.D. thesis, University of Wisconsin-Milwaukee.

Gerlach, S. A. 1971. On the importance of marine meiofauna for benthos communities. Oecologia 6:176-190. 1978. Food-chain relationships in subtidal silty sand marine sediments and the role of meiofauna in stimulating bacterial productivitiy. Oecologia 33: $5-69$.

Goloni, V. 1979. Benthic macro- and meioinvertebrates of Lake Ontario, 1977: Distribution and relative abundance. Fish. Res. Board Can., Fish. Mar. Serv. MS Rept. 1519.

Great Lakes Basin Commission. 1975. Water Quality. Great Lakes Basin Framework Study, Appendix 7. Ann Arbor, Michigan: Great Lakes Basin Commission.

Guille, A., and Soyer, J. 1974. Bionomie benthique du plateau continental de la cote Catalane Francaise. 8. Macrofaune et meiofaune, rapports quantitatifs et ciocenotiques. Vie Milieu 24(B):301-320.

Holopainen, I. J., and Paasivirta, L. 1977. Abundance and biomass of the meiozoobenthos in the oligotrophic and mesohumic Lake Paajarvi, southern Finland. Ann. Zool. Fennici 14:124-134.

Johnson, M. G., and Brinkhurst, R. O. 1971. Benthic community metabolism in Bay of Quinte and Lake Ontario. J. Fish. Res. Board Can. 28:1715-1725.

Lee, J. J., Tenore, K. R., Tietjen, J. H., and Mastropaolo, C. 1975. An experimental approach toward understanding the role of meiofauna in a detrital based food web. In Proc. of the 4th Natl. Symp. on Radioecol., pp. 140-147. Dowden, Hutchinson, and Ross, Inc., Stroudsburg, Pennsylvania.

Loveridge, C. C., and Cook, D. G. 1976. A preliminary report on the benthic macroinvertebrates of Georgian Bay and North Channel. Fish. Res. Board Can., Fish. Mar. Ser. Tech. Rept. 610.

Mare, M. F. 1942. A study of the marine benthic community with special reference to the micro-organisms. J. Mar. Biol. Ass. U.K. 25:517.

McIntyre, A. D. 1969. Ecology of marine meiobenthos. Biol. Rev. 44:245-290.

1977. Effects of pollution on inshore benthos. In Ecology of Marine Benthos, ed. B. C. Coull. Columbia, S.C.: University of S. Carolina Press.

McQueen, D. J. 1969. Reduction of zooplankton standing stock by predacious Cyclops bicuspidatus thomasi in Marion Lake, British Columbia. J. Fish. Res. Board Can. 26:1605-1618.

Milbrink, G. 1969. Microgradients at the mud-water 
interface. Institute of Freshwater Research, Drottingholm, Rept. 49, pp. 129-148.

Mozley, S. C. 1975. Preoperational investigations of zoobenthos in southeastern Lake Michigan near the Cook Nuclear Plant. University of Michigan, Great Lakes Research Division, Spec. Rept. 56, Ann Arbor, Michigan.

, and Garcia, L. C. 1972. Benthic macrofauna in the coastal zone of southeastern Lake Michigan. In Proc. of the 15th Conf. Great Lakes Res., pp. 102-116. Internat. Assoc. Great Lakes Res. , and Winnell, M. H. 1975. Macrozoobenthic species assemblages of southeastern Lake Michigan, U.S.A. Verh. Internat. Verein. Limnol. 19:922-931.

Nalepa, T. F., and Quigley, M. A. 1980. The macro- and meiobenthos of southeastern Lake Michigan near the mouth of the Grand River, 1976. NOAA Data Rept. ERL GLERL-17, Great Lakes Environmental Research Laboratory, Ann Arbor, Michigan. and 1981. The macro- and meiobenthos of southeastern Lake Michigan near the mouth of the Grand River, 1978. NOAA Data Rept. ERL GLERL-19, Great Lakes Environmental Research Laboratory, Ann Arbor, Michigan. , and Robertson, A. 1981a. Screen mesh size affects estimates of macro- and meio-benthos abundance and biomass in the Great Lakes. Can. J. Fish. Aquat. Sci. 38:1027-1034. and 1981b. Vertical distribution of the zoobenthos in southeastern Lake Michigan with evidence of seasonal variation. Freshwater Biol. 11: 87-96.

Patalas; K. 1969. Composition and horizontal distribution of crustacean plankton in Lake Ontario. J. Fish. Res. Board Can. 26:2135-2164.

1972. Crustacean plankton and the eutrophication of the St. Lawrence Great Lakes. J. Fish. Res. Board Can. 29:1451-1462.

Pennak, R. W. 1978. Freshwater Invertebrates of the United States, 2nd ed. New York: John Wiley and Sons, Inc.

Riemann, F., and Schrage, M. 1978. The mucus-trap hypothesis on feeding of aquatic nematodes and implications for biodegradation and sediment texture. Oecologia 34:75-88.
Sarkka, J., and Paasivirta, L. 1972. Vertical distribution and abundance of the macro- and meiofauna in the profundal sediments of Lake Paijanne, Finland. Ann. Zool. Fennici 9:1-9.

Scheibel, W. 1973. Quantitativ-okologische untersuchungen am uferfernen mesopsammon in der Kieler Bucht. Kieler Meeresforsch 29:58-68.

Siebel, E., and Ayers, J. C. 1977. Natural lake temperatures in the nearshore waters of southeastern Lake Michigan. J. Great Lakes Res. 3:1-9.

Sokal, R. R., and Rohlf, F. J. 1969. Biometry. San Francisco: W. H. Freeman and Company.

Sonzogni, W. C., Monteith, T. J., Bach, W. N., and Hughes, V. G. 1978. United States Great Lakes tributary loadings. International Joint Commission PLUARG Report, International Joint Commission, Windsor, Ontario.

Stevenson, R. J., and Stoermer, E. F. 1981. Quantitative differences between benthic algal communities along a depth gradient in Lake Michigan. J. Phycol. 17:29-36.

Stimpson, K. S., Brice, J. R., Barbour, M. T., and Howe, P. 1975. Distribution and abundance of inshore oligochaetes in Lake Michigan. Trans. Am. Microsc. Soc. 94:384-394.

Stripp, K. 1969. Das verhaltnis von makrofauna und meiofauna in den sedimenten der Helgolander Bucht. Veroff. inst. Meeresforsch. Bremerh. 12:143-148.

Tenore, K. R., Tietjen, J. H., and Lee, J. J. 1977. Effect of meiofauna on incorporation of aged eelgrass, Zostera marina, detritus by the polychaete Nephthys incisa. J. Fish. Res. Board Can. 34: 563-567.

Wieser, W. 1960. Benthic studies in Buzzards Bay. II. The meiofauna. Limnol. Oceanogr. 5:121-137.

, and Kanwisher, J. 1961. Ecological and physiological studies on marine nematodes from a small salt marsh near Woods Hole, Massachusetts. Limnol. Oceanogr. 6:262-270.

Wigley, R. L., and McIntyre, A. D. 1964. Some quantitative comparisons of offshore meiobenthos and macrobenthos south of Martha's Vineyard. Limnol. Oceanogr. 9:485-493. 